\title{
Aberrant Methylation Modifications Reflect Specific Drug Responses in Small Cell Lung Cancer
}

\section{Peixin Chen}

Tongji University Affiliated Shanghai Pulmonary Hospital https://orcid.org/0000-0002-4192-8396

\section{Haoyue Guo}

Tongji University Affiliated Shanghai Pulmonary Hospital

\section{Yu Liu}

Tongji University Affiliated Shanghai Pulmonary Hospital

\section{Bin Chen}

Tongji University Affiliated Shanghai Pulmonary Hospital

\section{Sha Zhao}

Tongji University Affiliated Shanghai Pulmonary Hospital

\section{Shengyu Wu}

Tongji University Affiliated Shanghai Pulmonary Hospital

\section{Wei Li}

Tongji University Affiliated Shanghai Pulmonary Hospital

\section{Lei Wang}

Tongji University Affiliated Shanghai Pulmonary Hospital

\section{Keyi Jia}

Tongji University Affiliated Shanghai Pulmonary Hospital

\section{Hao Wang}

Tongji University Affiliated Shanghai Pulmonary Hospital

\section{Minlin Jiang}

Tongji University Affiliated Shanghai Pulmonary Hospital

\section{Xuzhen Tang}

oncology and immunology $\mathrm{BU}$

Hui Qi

Oncology and immunology BU

\section{Chunlei Dai}

oncology and immunology BU

\section{Junyan Ye}

Tongji University Affiliated Shanghai Pulmonary Hospital Yayi He (D2250601@qq.com)

Tongji University Affiliated Shanghai Pulmonary Hospital 
Research

Keywords: Small cell lung cancer (SCLC), Methylation modifications, Epigenetic signature, Chemotherapy insensitivity, IncRNA-miRNA-mRNA network

Posted Date: July 23rd, 2020

DOI: https://doi.org/10.21203/rs.3.rs-46771/v1

License: (c) (i) This work is licensed under a Creative Commons Attribution 4.0 International License.

Read Full License

Version of Record: A version of this preprint was published at Genomics on May 1st, 2021. See the published version at https://doi.org/10.1016/j.ygeno.2020.12.045. 


\section{Abstract}

Background: Epigenetic alterations of specific genes are closely related to chemotherapeutic efficacy in various cancers. However, few comprehensive profiles of differentially methylated genes (DMGs) in small cell lung cancer (SCLC) were available. The current study aimed to explore the association between aberrant methylation modifications of coding and non-coding genes and chemotherapy insensitivity, thus constructing IncRNA-miRNA-mRNA regulatory network in SCLC.

Methods: In this study, methylated DNA immunoprecipitation sequencing (MeDIP-Seq) and RNA sequencing (RNA-Seq) was employed to six SCLC patients who were sensitive and insensitive to first-line standard chemotherapy. Then, we verified the therapeutic predictive effects of DMGs in 62 SCLC cell lines and constructed IncRNA-miRNA-mRNA network on the basis of different cohorts and databases.

Results: Of 4552 DMGs which were selected (fold change $\geq 2, p<0.01$ ) between chemo-sensitive and chemo-insensitive group, coding genes constituted the largest percentage (3873/4551, 85.08\%), followed by IncRNAs $(479 / 4551,10.52 \%)$ and miRNAs (162/4552, 3.56\%). Further, both two groups demonstrated two methylation peaks near transcription start site and transcription end site. Two IncRNA-miRNA-mRNA networks which based on genes that showed opposite results in genetic expression and epigenetic modifications suggested the extensive genome connection between chemotherapy efficacy-related noncoding RNAs (ncRNAs) and mRNAs. Combing four DMGs, including hsa-miR-34a, LINC00461, LINC01018, and LINC01484 could effectively predict first-line chemotherapy response in SCLC, indicating that they might play vital roles in SCLC chemotherapy insensitivity.

Conclusions: This study was the first to evaluate multiple drugs efficacy-related ncRNAs and mRNAs which were modified by methylation in SCLC. In addition, DMGs identified in our research might serve as predictors for chemotherapy effect and promising therapeutic targets to reverse drugs-insensitivity by complex IncRNA-miRNA-mRNA mechanisms in SCLC. Further comprehensive studies of these findings are worthy of expecting.

\section{Background}

Lung cancer is responsible for the higher morbidity and mortality rate than any other kinds of malignant tumor, among which small cell lung cancer (SCLC) accounts for about 10-15\% (1,2). As a highly malignant form of neuroendocrine tumor, the two-stage classification of SCLC remained widely used (3). For extensive-stage SCLC patients (ES-SCLC), the platinum-based combination regimen, including platinum plus etoposide (EP) and platinum plus irinotecan (IP), was still recommended as the first-line therapy. However, the median overall survival (OS) of the standard chemotherapy regimen for SCLC was only about one year or shorter because of the high incidence rate of primary or secondary chemotherapy insensitivity $(4,5)$. Moreover, about $40 \%$ clinical SCLC patients was insensitive to chemotherapeutic drugs, which affected the long-term prognosis of SCLC seriously (5-7). Consequently, exploring the 
molecules and mechanisms of chemotherapy insensitivity is the key to providing new therapeutic targets and improving clinical prognosis in SCLC.

Multiple researches illustrated the great influences of epigenetic alterations in the process of progression, metastasis and chemotherapy insensitivity in $\operatorname{SCLC}(8,9)$. Epigenetic mechanisms contain DNA methylation, differential expression of non-coding RNAs (ncRNAs), and chromosome remodeling, etc. Under the complex effects of epigenetic modifications, the changes of gene expression and the phenotype was heritable, without DNA sequence alterations (10). DNA methylation could modify the transcriptional activity of tumor associated genes, including oncogenes and suppressor genes, thus regulating carcinogenesis and tumor development (11-13). More specifically, the hypermethylation of promoter regions of coding genes, such as FHIT, MGMT, and RASSF1A, led to the gene silencing in lung cancer (13-16). On the contrary, the high levels of methylation in gene body contributed to the overexpression of genes, which was similar to the function of hypomethylation in tumor tissues (16-18). In terms of chemotherapy insensitivity, the expression of tumor suppressor genes, such as IGFB3, GSTP1, $M G M T$, and $R A R \beta 2$, was down-regulated in non-small cell lung cancer (NSCLC) drug-resistant cell lines by promoter hypermethylation, but few data were available in $\operatorname{SCLC}(19,20)$.

Other than coding RNAs, ncRNAs included long non-coding RNAs (IncRNAs) which more than 200 nucleotides in length, and microRNAs (miRNAs), the length of which was about 18-25 nucleotides, respectively $(21,22)$. Epigenetic modifications also occurred in IncRNAs and miRNAs. The hypermethylated status of promoter in IncRNAs and miRNAs, such as AFAP1-AS1, miR-205, miR-200, miR-196b, miR-34b/c, and miR-886-3p, was associated with the low expression of corresponding RNAs in SCLC and NSCLC, thus affecting the tumor growth and invasion (23-25). Mounting evidences investigated the significant roles of IncRNAs and miRNAs in chemotherapy insensitivity $(26,27)$. In SCLC drug-resistant cell lines, the aberrant expression of various IncRNAs and miRNAs was found, including IncRNA HOTTIP, IncRNA HOTAIR, miR-92a-2, miR-100, miR-134, miR-137, and miR-147, etc (28-33). However, the researches that focused on the comprehensive relationship between tumor-related genes, IncRNAs, miRNAs and the level of methylation in SCLC chemotherapy response was insufficient. The aim of this study was to identify epigenetic changes of coding and non-coding genes that influenced the efficacy of chemotherapy in SCLC by combining methylated DNA immunoprecipitation sequencing (MeDIP-Seq) and RNA sequencing (RNA-Seq). Moreover, we constructed the novel network of methylated IncRNAs, miRNAs and mRNAs, in order to better understand the complex mechanisms of chemotherapy insensitivity in SCLC. Then, we highlighted four therapeutic predictive epigenetic signatures for SCLC and verified their performances in 62 SCLC cell lines.

\section{Methods}

\section{Patients and clinical specimens}

The research involved six patients who underwent percutaneous transthoracic needle aspiration biopsy from 2018 to 2019 at Shanghai Pulmonary Hospital, China. All enrolled participants were diagnosed with 
SCLC by two independent pathologists. The tumor-node-metastasis (TNM) staging system of International Association for the Study of Lung Cancer (IASLC) and the two-stage system of Veterans Administration Lung Study Group (VALG) were adopted. The experiment was approved by the ethics committee of Shanghai Pulmonary Hospital (ethical number 18151). We collected lung biopsy samples after obtaining written informed consent from all subjects. All clinical specimens were kept at temperatures of below minus 80 degrees Celsius before the process of DNA extraction.

\section{MeDIP-seq}

For MeDIP-seq邓the PureLink Genomic DNA Mini Kit (K18200, Thermo) was applied to extract genomic DNA from pulmonary biopsy tissue. By means of a bioruptor (Diagenode), purified genomic DNA was sonicated to an average size within the scope of 100-500 base pair (bp). The end-repair of DNA fragments was followed by A-tailed and custom TruSeq adapters attached with the TreSeq DNA sample preparation Kit (Illumina).

Then, protein A + G magnetic beads bound to 5-methylcytidine $(5 \mathrm{mc})$ antibody or 5-hydroxylmethylcytidine $(5 \mathrm{hmc})$ antibody was employed to the test of immunology precipitation with DNA fragments linked to adapters. After amplifying for 15 cycles by polymerase chain reaction (PCR) method, the enriched methylated DNA libraries fully sequenced on Illumina HiSeq platform with the sequencing pattern of paired-end $2 \times 150$.

\section{Differentially methylated genes (DMGs) bioinformatic analysis}

A total of raw read data from MeDIP-Seq were processed by the removal of adapter sequences using the Cutadapt tool (version 1.12) (34), and low-quality sequences with Trimmomatic (version 0.39) (35). Next, the quality control of the remaining data was performed by Fastqc (version 0.11.9) (36), which calculated the amount of clean sequence reads and the proportion of identification error among 100 or 1000 bases. Subsequently, clean data were mapped to human genome through the usage of Bowtie2 (version 2.3.5.1) (37). MASC (version 2.0) were applied for the peak calling, which identified methylated enriched areas of aligned genomes (38). The determination of differentially methylated peaks of genes and the calculation of reads per kilobase per million (RPKM) depended on the method of DESeq2 in DiffBind, a R package (39). Finally, MeDIPseeker was employed to annotate, compare and visualize differentially methylated peaks among all specimens (40). Bioinformatic analyses were conducted using R 3.5.3 software (https://www.r-project.org/) and Python 3.8 software (https://www.python.org/).

DMGs needed to be satisfied with two conditions: first, the fold change was greater than or equal to two; second, the $p$ value less than 0.01 . The genome methylation levels of different clinical samples were analyzed, thus drawing the methylated density plot of $2 \mathrm{~kb}$ upstream and downstream of transcriptional sites. The differentially methylated regions of coding and non-coding genes were classified as promoter, intron, 5'UTR, 3'UTR, CDS, and distal intergenic.

\section{Signal transduction pathway analysis}


A Gene Ontology (GO) blot and a Kyoto Encyclopedia of Genes and Genomes (KEGG) pathway bar-blot for DMGs among all SCLC specimens were obtained by the R package called clusterProfiler. The annotations of GO (http://www.geneontology.org/) provide detailed information on the three major functions of genes and proteins, including cellular components, biological processes, and molecular function. The KEGG pathway database, a systematic database that integrates genome and function information, was carried out for enrichment analysis. The q value was generated through adjusting the value of $p$. $P$ value less than 0.05 and $q$ value less than 0.01 indicated the statistically significant enrichment.

\section{RNA-seq and differentially expressed genes (DEGs) identification}

After the extraction of RNA from six SCLC samples, KAPA RiboErase Kit (Human/Mouse/Rat, HMR) was used for the removal of ribosomal RNA (rRNA). The count and quality assessment of raw RNA data was performed by spectrophotometry and electrophoresis, as we reported before (27). Several methods were used for the construction and the quality control of the RNA library, including TruSeq RNA library preparation kit (Illumina, San Diego, CA, USA), quantitative polymerase chain reaction (qPCR), electrophoresis, and so forth. Thereafter, the Illumina HiSeqTM2000 platform demonstrated the RNA-seq. We employed TopHat software (version 2.1.1) and Cufflinks (version1.2.1), which based on the human genome and annotations from the public database, for sequence alignment, fragments per kilobase per million reads calculation, and DEGs visualization. The definition of DEGs was as suggested before (27).

\section{LncRNA-miRNA-mRNA interaction network construction}

The differentially expressed (DE) IncRNAs and miRNAs in SCLC were aligned to the DMGs detected by MeDIP-Seq. The regulatory network, which involved DElncRNAs with abnormal methylated status, DEmiRNAs with abnormal levels of methylation, and DEmRNAs, were constructed by Cytoscape software (version 3.7.1; https://cytoscape.org/) (41). The statistically significant miRNA/IncRNA-targeted genes were identified from the TarBase database (http://www.tarbase.com/) (42) and the ENCORI database (The Encyclopedia of RNA Interactomes; http://starbase.sysu.edu.cn/) $(43,44)$. The TarBase database was composed of the verified target genes of miRNA by experiments. The ENCORI platform, which is the latest version of starBase, provided a variety of interactome information among IncRNAs, miRNAs, and mRNAs. All selected target genes in the network were validated by reliable methods, including reported assay, western-blot, and qRCR.

\section{Validation of four therapeutic predictive epigenetic signatures for SCLC}

In order to verify therapeutic predictive values of four epigenetic signatures in SCLC, we used CellMiner database (https://discover.nci.nih.gov/cellminercdb/) (45). As one of cancer-related databases, CellMiner currently summarizes the pharmacogenomic data of five sources in total 118 SCLC cell lines. Detailed information that provided by CellMiner was as follows: expression levels of more than 60,000 genes, methylation levels of more than 20,000 genes, and drugs responses of more than 500 drugs, etc. Pearson's correlation coefficients range from -1 to 1 . P value less than 0.05 indicated the statistically 
significant difference. After downloading suitable methylation profiling and drug sensitivity dataset from CellMiner, R 3.5.3 software (https://www.r-project.org/) was used for visualizing differential methylation levels of corresponding genes between chemotherapy sensitive and insensitive group.

\section{Results}

\section{Clinical characteristics of SCLC patients}

The clinical pathological features of six SCLC patients enrolled in the research were summarized. All enrolled participants were male smokers, with an average age of 64.2 years (range: $54-69$ years). More specifically, five out of six confirmed with SCLC patients were older than 60 years old. ES-SCLC comprised the highest proportion of the total $(4 / 6,66.7 \%)$, while limited-stage SCLC patients (LD-SCLC) made up $33.3 \%(2 / 6)$. The group of chemotherapy sensitivity consisted of three patients who achieved partial response (PR), while three members of chemo-insensitive group experienced stable disease (SD) or progressive disease (PD) after first-line standard chemotherapy (Table 1).

\section{MeDIP-Seq analysis results}

For MeDIP-Seq $囚 a$ large number of raw reads were obtained from six SCLC fine-needle aspiration specimens, $82.02 \times 10^{6}\left( \pm 11.94 \times 10^{6}\right)$ raw reads of chemo-sensitive group, and $83.43 \times 10^{6}\left( \pm 1.23 \times 10^{6}\right)$ raw reads of chemo-insensitive group, respectively. The mapped ratios of the group of chemotherapy sensitivity and insensitivity were over $95 \%$, while the unique mapped ratios of these two groups were slightly exceeding $60 \%$.

Comparing these two datasets, no statistical differences were found ( $p>0.05$; Table 2).

\section{DMGs profile and methylation enrichment distribution}

The identification of DMGs in SCLC chemo-sensitive and chemo-insensitive tissues were performed by MeDIP-Seq. Of 4552 DMGs which met selection criterias (fold change $\geq 2, p<0.01$ ), coding genes constituted the largest percentage (3873/4551, 85.08\%), followed by IncRNAs $(479 / 4551,10.52 \%)$ and miRNAs (162/4552, 3.56\%), while other ncRNAs occupied a relatively small proportion $(38 / 4552,0.83 \%$; Figure 1A). The percentage of hypermethylated coding genes, IncRNAs, miRNAs, and ncRNAs in the group of chemotherapy sensitivity were $60.86 \%, 57.20 \%, 56.17 \%, 50.00 \%$, respectively (Figure 1B). Further, both these two groups demonstrated two methylation peaks near the scopes of transcription start site (TSS) and transcription end site (TES) (Figure 1C). Specifically, the methylation enrichment of all DMGs spread over the promoter region, the intron region, and the distal intergenic region. The proportion of methylation enrichment in above three mentioned regions was around 30\% among the differentially hypermethylated protein-coding genes (Figure 1D). For IncRNAs and miRNAs, the distal intergenic region shared the highest enrichment of methylation (Figure 1E and 1F). The methylation enrichment in the 5'UTR region and the downstream region was observed in protein-coding genes, but hardly discovered in IncRNAs and miRNAs. 
The heatmap of systematic clustering analysis helped grasp the comprehensive picture of methylation differences in SCLC. As the Figure 2 showed, the genome methylation level of chemo-sensitive group was higher than it of chemo-insensitive group. Compared with the group of chemotherapy sensitivity, 1516 coding genes, 205 IncRNAs, and 71 miRNAs were differentially hypermethylated in the chemo-insensitive group.

\section{GO and KEGG pathway analysis for DMGs}

The functional enrichment analysis of DMGs in SCLC tumor tissues incorporated the GO and KEGG pathway analysis. The results of $\mathrm{GO}$ analysis indicated that biological process was principally related to the hypermethylated genes of the chemo-insensitive group, molecular function ranked the second, while cellular component was the least associated enrichment. The top 5 DMG-related terms were as follows: muscle organ development, muscle tissue development, striated muscle tissue development, synaptic membrane, and DNA-binding transcription activator activity which is RNA polymerase II-specific (Table 3 and Figure 3). According to KEGG pathway enrichment analysis, the Wnt signaling pathway was the most enriched pathways of DMGs, followed by signaling pathways regulating pluripotency of stem cells, glycerophospholipid metabolism, synaptic vesicle cycle, and so on (Table 4 and Figure 4).

\section{Different expression patterns of genes in SCLC are associated with the levels of methylation}

The genes methylation levels assessed by MeDIP-Seq and the genes expression levels evaluated by RNAseq were combined together to fully evaluate the relationship between gene methylation and expression in SCLC chemo-insensitive tissues. Of 1516 differentially hypermethylated protein-coding genes in chemo-insensitive tissue, 1102 genes overexpressed (1102/1516, 72.7\%), whereas the expression of 414 genes were decreased (414/1516, 27.3\%; Figure 5A). Likewise, 931 overexpressed genes comprised $39.5 \%$ of 2357 hypomethylated protein-coding genes, while 1426 genes with low expression made up the rest (1426/2357,60.5\%; Figure 5A). The top 10 hyper- and hypo- methylated genes showing differential expression in chemo-insensitive tissues compared with chemo-sensitive tissues were presented in Table 5. For 71 hypermethylated miRNAs, only the expression of 12 miRNAs was decreased in chemoinsensitive group (12/71, 16.9\%; Figure 5B). Most of the remaining hypermethylated miRNAs demonstrated high level gene expression $(59 / 71,83.1 \%)$. More than half of hypomethylated miRNAs expression were downregulated $(53 / 91,58.2 \%)$, while the expression of the rest hypomethylated miRNAs were upregulated $(38 / 91,41.8 \%)$. Table 6 displayed the top 10 list of miRNAs which showed opposite methylation level and gene expression across six SCLC samples. For IncRNAs, a total of 102 differentially methylated IncRNAs expressed differentially, of which 78 IncRNAs with hypomethylation and high expression, and 24 IncRNAs with hypermethylation and low expression (Figure 5C). Table 7 summarized the top 10 list of differential IncRNAs in chemo-insensitive group. The correlation between methylated status and expression level of DMGs, including coding genes, IncRNAs, and miRNAs, was statistically significant (both $p<0.001$ ).

Then, the significant relationship between methylation levels and expression levels of several chemotherapy efficacy-related genes, such as CELF2, CRMP1, FAM135B, PON3, and ZNF529, was 
validated across 65 SCLC cell lines (Figure S1). Pearson's correlation coefficients illustrated the negative correlations between the methylation levels and gene expression (both $p<0.05$ ), which was consistent with our findings and further emphasized the close correlation between methylation and gene expression in SCLC.

\section{LncRNA-miRNA-mRNA interaction network}

To explore the regulatory relationship between DMGs that expressed differentially and their candidate targeted genes, IncRNA-miRNA-mRNA interaction networks were constructed. The interaction network in Figure 6 contained eight miRNAs that hyper- or hypo- methylated in SCLC by the results of MeDIP-Seq and showed up- or down- regulated expression by the results of RNA-Seq, 219 target mRNAs, and 32 IncRNAs. In particular, hsa-miR-34a owned the richest target genes, totaling 70 mRNAs and 7 IncRNAs. Apart from hsa-miR-1269a and hsa-miR-589, the connection among other miRNAs was revealed in different degree. For example, hsa-miR-34a shared some target mRNAs with hsa-miR-148a, including MET, MYC, BCL2, GAS1, TGIF2, WNT1, and MAP3K9. In addition, TP53, MYB, and BIRC5 were common target mRNAs for hsa-miR-34a and hsa-miR-150. OIP5-AS1, was the only IncRNA which interacted with three candidate miRNAs, including hsa-miR-320d, hsa-miR-148a, and hsa-miR-150.

Among the top 10 hypermethylation and low expression or hypomethylation and high expression IncRNAs list, 10 differentially methylated IncRNAs in SCLC were selected for generating the IncRNAmiRNA-mRNA interaction network (Figure 7). All enrolled IncRNAs, including LINC00461, LINC01006, LINC01018, LINC01121, LINC01194, LINC01435, LINC02298, RDH10-AS1, H1FX-AS1, and CATIP-AS1, showed the total of 44 predictive target miRNAs and 122 mRNAs. Specificially, the regulatory network of LINC01435 was the largest. We noticed that both LINC01006 and LINC02298 interacted with hsa-miR-708 and hsa-miR-28. The networks of LINC00461 and H1FX-AS1 were linked by hsa-miR-485. However, none of enrolled IncRNAs owned the common target mRNAs.

\section{Four therapeutic predictive epigenetic signatures for SCLC}

By means of literature consulting, we found methylation levels four epigenetic signatures among above top10 lists, including hsa-miR-34a, LINC01484, LINC00461, and LINC01018, were closely related to tumor development, progression, and drug resistance. Hence, we firstly evaluated the effects of methylation level of single gene on chemotherapy drugs sensitivity, including etoposide, irinotecan, carboplatin, and cisplatin (Table S1). The predictive value of single epigenetic signature on SCLC first-line chemotherapy drug response in SCLC cell lines $(\mathrm{N}=62)$ agreed well with our findings from clinical specimens.

Unfortunately, only the methylation level of LINC01484 showed significant predictive value on etoposide sensitivity $(r=0.28, p=0.027)$. Then, to better predict drug sensitivity in SCLC, we combined four epigenetic features together and explored the corresponding predictive value (Figure 8 and Table S1). When compared with individual epigenetic feature, the analysis results illustrated better predictive value of hsamiR-34a in combination with LINC01484, LINC00461, and LINC01018 in both etoposide, irinotecan and carboplatin response with decreased $p$ value. Significantly, four epigenetic signatures for SCLC presented the best prediction ability on etoposide sensitivity than others $(r=0.33, p=0.0083)$. 


\section{Discussion}

Epigenetic mechanisms, which contain DNA methylation, aberrant expression of miRNAs and IncRNAs, fulfilled an important role in cancers including but not limited to SCLC (8). Moreover, a growing number of evidences emphasized the contribution of epigenetic alternation of cancer-related ncRNAs to chemotherapy insensitivity $(19,20,28-33)$. In the current experiment, we explored the unique methylation patterns of protein-coding and non-coding genes between SCLC patients who experienced PR and patients who were insensitive to the standard chemotherapy. Further, the correlation between methylation levels and SCLC-related ncRNAs expression was evaluated through combing the results of MeDIP-Seq and RNA-SEq. Then, we established two IncRNA-miRNA-mRNA interaction networks which based on two types of DMGs, 8 miRNAs and 10 IncRNAs, separately. Finally, four epigenetic signatures that we developed by clinical samples and verified by 62 SCLC cell lines could effectively predict chemotherapy response in SCLC

Given the highly coordination and diversity of epigenetic modifications in malignancy, some epigenetic regulation might be critical to the formation, progression, recurrence and resistance of tumors (46). CpG islands which are mainly located in the region of TSS of genes have the highest methylated rate (47). In the present study, we demonstrated that the highest methylated peak in both chemo-sensitive and chemoinsensitive groups were at the TES site, while another methylated peak was observed at the TSS site. Further, we found relatively high methylated rate of promoter region in the protein-coding genes and that it of distal intergenic region of miRNAs and IncRNAs, revealing that different methylated patterns between coding and non-coding genes in SCLC might contribute to SCLC etiology and therapeutic efficacy.

The heat map depicted the methylation profiles of DMGs between chemo-sensitive and chemo-insensitive group. The GO analysis identified that DMGs in the chemo-insensitive group mainly enriched in the process of muscle-related development, the component of synaptic membrane, and the function of DNAbinding transcription activator activity. It was reported that muscle loss was closely related to cachexia and poor prognosis in various kinds of cancer, including lung cancer $(48,49)$. In SCLC, Kalari et al.(50) also revealed that the enrichment of DMGs were principally presented in processes of neuronal differentiation and acting as transcription factors, which was consistent with our GO results and enhanced the dependability of our research. Several studied also revealed that synuclein- $y$, as one of neuronal proteins, induced drug resistance in breast cancer, lung cancer, and so on (51-53). However, little clinical studies were conducted to explore the relationship between above methylation-related GO terms and chemotherapy response in SCLC. To the best of our knowledge, we firstly linked these meaningful cellular components, biological processes, and molecular function to the chemotherapy insensitivity in SCLC. The KEEG pathway analysis of DMGs in the chemo-insensitive group highlighted the significant roles of Wnt signaling pathway, signaling pathways regulating pluripotency of stem cells, metabolism-related pathways, and synaptic vesicle cycle pathway in the insensitivity of chemotherapy in SCLC. The aberrant methylation level of WNT5A, APC, CTNND2, SFRP4, PLCB2, CCND2, PRICKLE2, $T C F 7 L 1, S M A D 3, R A C 1, F Z D 2$ were found in the Wnt signaling pathway. For relapsed SCLC patients, Wagner et al(54). found that the activation of Wnt signaling pathway mediated chemoresistance. The 
mechanisms of Wnt signaling pathway in chemoresistance were as follows: apoptosis-related, DNA repair-related, immune evasion-related, drug accumulation and metabolism procedure (55-57). Tumor stem cells (TSCs) possess self-renewal capacity and extensive proliferative potential, thus resulting in the maintenance, invasion, metastasis, relapses and drugs-resistance of a variety of cancers (58). In SCLC, Eramo et al. (59) and Sarvi et al. (60) reported that the higher expression of CD133 in TSCs was responsible to the drugs-resistance, including cisplatin, etoposide, paclitaxel and gemcitabine. Yu et al. (61) demonstrated that the overexpression of ERK, MDR and ABCG2 in a281(+) TSCs participated in the drugs-resistance in SCLC by regulating voltage-dependent calcium channel a281. Given all these, we hypothesized that the enrichment of DMGs in these GO terms and KEGG pathways might promote differential expression level of corresponding genes and poorer chemotherapy efficacy by complex mechanisms, thus contributing to poorer outcome in SCLC.

Furthermore, the opposite results in genetic expression and epigenetic modifications were shown in SCLC, suggesting the potential impact of methylation level on the expression status of corresponding genes. We respectively summarized the top 10 hyper- and hypo- methylated curative effect-related genes which showing reverse expression among SCLC clinical samples. In addition, the statistically significant correlations between methylation levels and gene expression level of some corresponding were observed across SCLC cell lines. The widely connection and mutual regulation between IncRNAs and miRNAs was investigated in various cancers $(62,63)$. Considering both IncRNAs and miRNAs could modulate gene expression either directly or indirectly, we established IncRNA-miRNA-mRNA interaction networks of efficacy-associated DMGs in SCLC. However, the influences of most differentially methylated miRNAs and IncRNAs in chemotherapy response were not well characterized in SCLC. In our study, hsa-miR-34a which showed hypermethylation status and low expression level targeted the maximum number of genes in the differentially methylated miRNAs-based network. In multiple cancer types, many research results demonstrated that the expression level of hypermethylated hsa-miR-34a was downregulated, which further strengthened the relationship between methylation and expression level (64-66). It was reported that hsa-miR-34a, as one of tumor suppressor miRNAs, participated in the drugs-resistance network of chronic lymphocytic leukemia and $\operatorname{NSCLC}(67,68)$. Regrettably, the mechanisms of hsa-miR-34a in regulating chemotherapy insensitivity were not fully illustrated in SCLC owing to the complex correlation between hsa-miR-34a and other genes, such as TP53, MYC, EMT, HOTAIR, and so on $(33,69,70)$. We also observed the higher expression level and hypomethylated status of LINC00461 and LINC01484, the lower expression level and hypermethylated status of LINC01018 in the SCLC chemo-insensitive group compared with the chemo-sensitive group, indicating the underlying function of these IncRNAs in drugs insensitivity. In rectal cancer, the higher expression level of LINC00461 induced cisplatin-based resistance by regulating miR-593-5p and cyclin D1 level (71). LINC01484, which was considered as one of independent prognostic factors for bladder urothelial carcinoma, improved the metastatic potential of cancer cells (72). LINC01018, which acted as a tumor suppressor, regulated the progression of liver cancer (73). Nonetheless, little data was known for the function and the methylation profiles of these IncRNAs in SCLC. Therefore, the current study put forward new views for the methylation profiles of therapeutic efficacy-associated miRNAs and IncRNAs candidates in SCLC. 
According to the Pearson's correlation coefficients, results of relationship between four key genes and drug sensitivity in SCLC cell lines were highly consistent with those concluded by using clinical samples. For example, hypomethylation levels of hsa-miR-34a, LINC01484 and LINC00461, and hypermethylation level of LINC01018 were found among clinical SCLC patients with chemotherapy-insensitivity. Similar results were also found in SCLC cell lines, thus further validating our results and enhancing the credibility. However, some conflicting findings occurred in irinotecan and platinum. Firstly, the level of LINC00461 methylation was negatively correlated with irinotecan sensitivity in cell lines, which was contrary to our clinical finding. In our view, the principal reason was that all enrolled SCLC patients underwent EP treatment (etoposide plus carboplatin/cisplatin), instead of irinotecan treatment, suggesting that methylation signatures varied from drug to drug. Secondly, both hsa-miR-34a and LINC00461 showed controversial predictive values in platinum. The combined therapy of etoposide and platinum in clinical patients might lead to the cumulative results of methylation levels of hsa-miR-34a and LINC00461. Thus, MeDIP-seq displayed the comprehensive predictive effect of corresponding genes on clinical combination therapy, instead of single drug. Rather, analysis of SCLC cell lines focused on the correlation of epigenetic features to the single drug sensitivity, which may result in opposite outcomes between clinic and laboratory. In addition, the predictive ability of single epigenetic characteristic was unsatisfied in SCLC, while encouraging improvement of predictive ability was found after combining four signatures together. In comparison with the significant outcome in etoposide response prediction, predictive differences of irinotecan and carboplatin was not statistically significant. Given all these, combining four epigenetic features together contributed to better predictive value on the efficacy of chemotherapeutic drugs in clinical practice. Moreover, further study would be needed to explore specific factors to predictive other drugs response.

Epigenetic therapies might be the promising strategy to tackle drugs-insensitivity and enhance curative effect in SCLC $(8,9)$. RRx-001 was the epigenetic and immunity inhibitor which could reverse platinumresistance. A completed phase 2 clinical trial, called QUADRUPLE THREAT (NCT02489903), applied RRx001 plus EP treatment to refractory SCLC patients and achieved cheerful efficacy for the first time (74). An ongoing phase 3 clinical trial, called REPLATINUM (NCT03699956), will further explore the application of RRx-001 in SCLC (75). Other epigenetic drugs, including DS-3201b (NCT03879798), CC-486 (oral Azacitidine, NCT02223052), Vidaza (NCT02223052), INCB059872 (NCT02712905), and SGI-110 (guadecitabine, NCT03913455) are also undergoing clinical trials in SCLC. We are looking forward the meaningful results of theses clinical trials. In addition, in consideration of the obvious restriction of our study which analyzed with a relatively small sample size, further studies with larger sample sizes are expected to fully investigate the function and epigenetic alterations of these genes in SCLC patients who insensitive to chemotherapy.

\section{Conclusions}

In this study, we compared the high-throughout sequencing results of MeDIP-seq and RNA-Seq to identify a variety of protein-coding genes, IncRNAs and miRNAs which are differentially methylated and expressed in SCLC chemo-insensitive tissues compared with chemo-sensitive tissues. Moreover, we 
outlined IncRNA-miRNA-mRNA networks and highlighted some DMGs which are likely to be predictors for chemotherapy effect and promising therapeutic targets to help SCLC patients who suffer from drugsinsensitivity. The main roles, epigenetic alterations, and mutual regulation of these chemo-insensitivityrelated genes in SCLC should be deeply and comprehensively illuminated in further researches.

\section{List Of Abbreviations}

bp, base pair; DE, differentially expressed; DMGs, differentially methylated genes; ES-SCLC, extensivestage SCLC patients; EP, platinum plus etoposide; GO, Gene Ontology; IP, platinum plus irinotecan; IASLC, International Association for the Study of Lung Cancer; KEGG, Kyoto Encyclopedia of Genes and Genomes; IncRNAs, long non-coding RNAs; LD-SCLC, limited-stage SCLC; MeDIP-Seq, methylated DNA immunoprecipitation sequencing; miRNAs, microRNAs; ncRNAs, non-coding RNAs; NSCLC, non-small cell lung cancer; OS, overall survival; PD, progressive disease; PR, partial response; PCR, polymerase chain reaction; $\mathrm{PPCR}$, quantitative polymerase chain reaction; RPKM, reads per kilobase per million; RNA-Seq, RNA sequencing; SCLC, small cell lung cancer; SD, stable disease; TNM, tumor-node-metastasis; TSS, transcription start site; TES, transcription end site; VALG, Veterans Administration Lung Study Group; 5mc, 5-methylcytidine; 5hmc, 5-hydroxyl-methylcytidine.

\section{Declarations}

Ethics approval and consent to participate: The authors are accountable for all aspects of the work in ensuring that questions related to the accuracy or integrity of any part of the work are appropriately investigated and resolved. The study was approved by Shanghai Pulmonary Hospital ethics committee (No. 18151). All participants gave their informed consent.

Consent for publication: All participants gave their informed consent for publication.

Availability of data and materials: The datasets used and analysed during the current study are available from the corresponding author on reasonable request.

Competing interests: The authors declare that they have no competing interests.

Funding. This study was supported in part by a grant of young talents in Shanghai, National Natural Science Foundation of China (81802255), Young Talents in Shanghai (2019QNBJ), 'Dream Tutor' Outstanding Young Talents Program (fkyq1901), Clinical Research Project of Shanghai Pulmonary Hospital (fk18005), Key Discipline in 2019 (oncology), Project of Shanghai Municipal Science and Technology Commission (Project of Municipal Science and Technology Commission), and Scientific research project of Shanghai Pulmonary Hospital (fkcx1903).

Authors' contributions $[(I)$ Conception and design: Peixin Chen, Yayi He; (II) Administrative support: Yayi He; (III) Provision of study materials or patients: Peixin Chen; (IV) Collection and assembly of data: Peixin 
Chen; (V) Data analysis and interpretation: Peixin Chen; (VI) Manuscript writing: All authors; (VII) Final approval of manuscript: All authors.

Acknowledgements: Not applicable.

Authors' information: Not applicable.

\section{References}

1. Siegel RL, Miller KD, A. J. Cancer statistics, 2019. CA: a cancer journal for clinicians. 2019;69(1):7-34.

2. Byers L, Rudin C. Small cell lung cancer: where do we go from here? Cancer. 2015;121(5):664-72.

3. Micke P, Faldum A, Metz T, Beeh KM, Bittinger F, Hengstler JG, et al. Staging small cell lung cancer: Veterans Administration Lung Study Group versus International Association for the Study of Lung Cancer-what limits limited disease? Lung cancer (Amsterdam, Netherlands). 2002;37(3):271-6.

4. Hanna N, Bunn PA, Jr., Langer C, Einhorn L, Guthrie T, Jr., Beck T, et al. Randomized phase III trial comparing irinotecan/cisplatin with etoposide/cisplatin in patients with previously untreated extensive-stage disease small-cell lung cancer. Journal of clinical oncology : official journal of the American Society of Clinical Oncology. 2006;24(13):2038-43.

5. Lara PN, Jr., Natale R, Crowley J, Lenz HJ, Redman MW, Carleton JE, et al. Phase III trial of irinotecan/cisplatin compared with etoposide/cisplatin in extensive-stage small-cell lung cancer: clinical and pharmacogenomic results from SWOG S0124. Journal of clinical oncology : official journal of the American Society of Clinical Oncology. 2009;27(15):2530-5.

6. Paz-Ares L DM, Chen Y, Reinmuth N, Hotta K, Trukhin D, Statsenko G, Hochmair MJ, Özgüroğlu M, Ji JH, Voitko O, Poltoratskiy A, Ponce S, Verderame F, Havel L, Bondarenko I, Kazarnowicz A, Losonczy G, Conev NV1, Armstrong J, Byrne N, Shire N, Jiang H, Goldman JW; CASPIAN investigators. Durvalumab plus platinum-etoposide versus platinum-etoposide in first-line treatment of extensivestage small-cell lung cancer (CASPIAN): a randomised, controlled, open-label, phase 3 trial. Lancet (London, England). 2019;394(10212):1929-39.

7. Chen S, He Y, Liu J, Chen X, Yu J, Li W, et al. Third-Generation TKI Resistance Due to SCLC Transformation: A Case Report and Brief Review. OncoTargets and therapy. 2019;12:11305-11.

8. Quintanal-Villalonga A, Molina-Pinelo S. Epigenetics of lung cancer: a translational perspective. Cellular oncology (Dordrecht). 2019;42(6):739-56.

9. Duruisseaux M, Esteller M. Lung cancer epigenetics: From knowledge to applications. Seminars in cancer biology. 2018;51:116-28.

10. Stonestrom AJ. The Key Role of Epigenetics in Human Disease. The New England journal of medicine. 2018;379(4):400.

11. Dor Y, Cedar H. Principles of DNA methylation and their implications for biology and medicine. Lancet (London, England). 2018;392(10149):777-86. 
12. Koch A, Joosten SC, Feng Z, de Ruijter TC, Draht MX, Melotte V, et al. Analysis of DNA methylation in cancer: location revisited. Nature reviews Clinical oncology. 2018;15(7):459-66.

13. Licchesi JD, Westra WH, Hooker CM, Machida EO, Baylin SB, Herman JG. Epigenetic alteration of Wnt pathway antagonists in progressive glandular neoplasia of the lung. Carcinogenesis. 2008;29(5):895-904.

14. Licchesi JD, Westra WH, Hooker CM, Herman JG. Promoter hypermethylation of hallmark cancer genes in atypical adenomatous hyperplasia of the lung. Clinical cancer research : an official journal of the American Association for Cancer Research. 2008;14(9):2570-8.

15. Sozzi G, Veronese ML, Negrini M, Baffa R, Cotticelli MG, Inoue H, et al. The FHIT gene 3p14.2 is abnormal in lung cancer. Cell. 1996;85(1):17-26.

16. Baylin SB, Jones PA. A decade of exploring the cancer epigenome - biological and translational implications. Nature reviews Cancer. 2011;11(10):726-34.

17. Tarakhovsky A. Tools and landscapes of epigenetics. Nature immunology. 2010;11(7):565-8.

18. Feinberg AP, Vogelstein B. Hypomethylation distinguishes genes of some human cancers from their normal counterparts. Nature. 1983;301(5895):89-92.

19. Ibanez de Caceres I, Cortes-Sempere M, Moratilla C, Machado-Pinilla R, Rodriguez-Fanjul V, ManguánGarcía C, et al. IGFBP-3 hypermethylation-derived deficiency mediates cisplatin resistance in nonsmall-cell lung cancer. Oncogene. 2010;29(11):1681-90.

20. Pasini A, Paganelli G, Tesei A, Zoli W, Giordano E, Calistri D. Specific Biomarkers Are Associated with Docetaxeland Gemcitabine-Resistant NSCLC Cell Lines. Translational oncology. 2012;5(6):461-8.

21. Schmitt AM, Chang HY. Long Noncoding RNAs in Cancer Pathways. Cancer cell. 2016;29(4):452-63.

22. Bartel DP. MicroRNAs: genomics, biogenesis, mechanism, and function. Cell. 2004;116(2):281-97.

23. He J, Wu K, Guo C, Zhou JK, Pu W, Deng Y, et al. Long non-coding RNA AFAP1-AS1 plays an oncogenic role in promoting cell migration in non-small cell lung cancer. Cellular and molecular life sciences : CMLS. 2018;75(24):4667-81.

24. Tellez CS, Juri DE, Do K, Picchi MA, Wang T, Liu G, et al. miR-196b Is Epigenetically Silenced during the Premalignant Stage of Lung Carcinogenesis. Cancer research. 2016;76(16):4741-51.

25. Tellez CS, Juri DE, Do K, Bernauer AM, Thomas CL, Damiani LA, et al. EMT and stem cell-like properties associated with miR-205 and miR-200 epigenetic silencing are early manifestations during carcinogen-induced transformation of human lung epithelial cells. Cancer research. 2011;71(8):308797.

26. Huang J, Peng J, Guo L. Non-coding RNA: a new tool for the diagnosis, prognosis, and therapy of small cell lung cancer. Journal of thoracic oncology : official publication of the International Association for the Study of Lung Cancer. 2015;10(1):28-37.

27. Kuang $P$, Chen $P$, Wang $L$, Li W, Chen $B$, Liu $Y$, et al. RNA sequencing analysis of small cell lung cancer reveals candidate chemotherapy insensitivity long noncoding RNAs and microRNAs. Annals of translational medicine. 2020;8(4):121. 
28. Xiao F, Bai Y, Chen Z, Li Y, Luo L, Huang J, et al. Downregulation of HOXA1 gene affects small cell lung cancer cell survival and chemoresistance under the regulation of miR-100. European journal of cancer (Oxford, England : 1990). 2014;50(8):1541-54.

29. Li P, Ma L, Zhang Y, Ji F, Jin F. MicroRNA-137 down-regulates KIT and inhibits small cell lung cancer cell proliferation. Biomedicine \& pharmacotherapy = Biomedecine \& pharmacotherapie. 2014;68(1):712.

30. Ranade AR, Cherba D, Sridhar S, Richardson P, Webb C, Paripati A, et al. MicroRNA 92a-2*: a biomarker predictive for chemoresistance and prognostic for survival in patients with small cell lung cancer. Journal of thoracic oncology : official publication of the International Association for the Study of Lung Cancer. 2010;5(8):1273-8.

31. Guo L, Zhou Y, Sun Y, Zhang F. Non-receptor tyrosine kinase Etk regulation of drug resistance in small-cell lung cancer. European journal of cancer (Oxford, England : 1990). 2010;46(3):636-41.

32. Sun Y, Hu B, Wang Q, Ye M, Qiu Q, Zhou Y, et al. Long non-coding RNA HOTTIP promotes BCL-2 expression and induces chemoresistance in small cell lung cancer by sponging miR-216a. Cell death \& disease. 2018;9(2):85.

33. Fang S, Gao H, Tong Y, Yang J, Tang R, Niu Y, et al. Long noncoding RNA-HOTAIR affects chemoresistance by regulating HOXA1 methylation in small cell lung cancer cells. Laboratory investigation; a journal of technical methods and pathology. 2016;96(1):60-8.

34. Martin M. Cutadapt removes adapter sequences from high-throughput sequencing reads. Bioinformatics (Oxford, England). 2011;30(15):2114-20.

35. Bolger AM, Lohse M, Usadel B. Trimmomatic: a flexible trimmer for Illumina sequence data. Bioinformatics (Oxford, England). 2014;30(15):2114-20.

36. S. A. FastQC: a quality control tool for high throughput sequence data.Available at http://www.bioinformatics.babraham.ac.uk/projects/fastqc/. . 2010.

37. Langmead B, Salzberg SL. Fast gapped-read alignment with Bowtie 2. Nature methods. 2012;9(4):357-9.

38. al. Ze. Model-based Analysis of MeDIP-Seq (MACS). . Genome Biol. 2008;9(9):R137.

39. Ross-Innes CS, Stark R, Teschendorff AE, Holmes KA, Ali HR, Dunning MJ, et al. Differential oestrogen receptor binding is associated with clinical outcome in breast cancer. Nature. 2012;481(7381):38993.

40. Guangchuang Yu L-GW, Qing-Yu A. MeDIPseeker: an R/Bioconductor package for MeDIP peak annotation, comparison and visualization. Bioinformatics (Oxford, England). 2015;31(14):2382-3.

41. Shannon P, Markiel A, Ozier O, Baliga NS, Wang JT, Ramage D, et al. Cytoscape: a software environment for integrated models of biomolecular interaction networks. Genome research. 2003;13(11):2498-504.

42. Chou CH, Shrestha S, Yang CD, Chang NW, Lin YL, Liao KW, et al. miRTarBase update 2018: a resource for experimentally validated microRNA-target interactions. Nucleic acids research. 2018;46(D1):D296-d302. 
43. Zhou KR LS, Cai L, Bin L, et al. ENCORI: The Encyclopedia of RNA Interactomes.

44. Li JH, Liu S, Zhou H, Qu LH, Yang JH. starBase v2.0: decoding miRNA-ceRNA, miRNA-ncRNA and protein-RNA interaction networks from large-scale CLIP-Seq data. Nucleic acids research. 2014;42(Database issue):D92-7.

45. Rajapakse VN, Luna A, Yamade M, Loman L, Varma S, Sunshine M, et al. CellMinerCDB for Integrative Cross-Database Genomics and Pharmacogenomics Analyses of Cancer Cell Lines. iScience. 2018;10:247-64.

46. Schübeler D. Function and information content of DNA methylation. Nature. 2015;517(7534):321-6.

47. Jones PA. Functions of DNA methylation: islands, start sites, gene bodies and beyond. Nature reviews Genetics. 2012;13(7):484-92.

48. Johns N, Stephens NA, Fearon KC. Muscle wasting in cancer. The international journal of biochemistry \& cell biology. 2013;45(10):2215-29.

49. Busquets S, Toledo M, Orpí M, Massa D, Porta M, Capdevila E, et al. Myostatin blockage using actRIIB antagonism in mice bearing the Lewis lung carcinoma results in the improvement of muscle wasting and physical performance. Journal of cachexia, sarcopenia and muscle. 2012;3(1):37-43.

50. Kalari S, Jung M, Kernstine KH, Takahashi T, Pfeifer GP. The DNA methylation landscape of small cell lung cancer suggests a differentiation defect of neuroendocrine cells. Oncogene. 2013;32(30):355968.

51. Singh VK, Jia Z. Targeting synuclein-gamma to counteract drug resistance in cancer. Expert opinion on therapeutic targets. 2008;12(1):59-68.

52. Pan ZZ, Bruening W, Giasson BI, Lee VM, Godwin AK. Gamma-synuclein promotes cancer cell survival and inhibits stress- and chemotherapy drug-induced apoptosis by modulating MAPK pathways. The Journal of biological chemistry. 2002;277(38):35050-60.

53. Gonçalves A, Braguer D, Kamath K, Martello L, Briand C, Horwitz S, et al. Resistance to Taxol in lung cancer cells associated with increased microtubule dynamics. Proceedings of the National Academy of Sciences of the United States of America. 2001;98(20):11737-42.

54. Wagner AH, Devarakonda S, Skidmore ZL, Krysiak K. Recurrent WNT pathway alterations are frequent in relapsed small cell lung cancer. Nature communications. 2018;9(1):3787.

55. Spranger S, Bao R, Gajewski TF. Melanoma-intrinsic $\beta$-catenin signalling prevents anti-tumour immunity. Nature. 2015;523(7559):231-5.

56. VanKlompenberg MK, Bedalov CO, Soto KF, Prosperi JR. APC selectively mediates response to chemotherapeutic agents in breast cancer. BMC cancer. 2015;15:457.

57. Jaiswal AS, Narayan S. Assembly of the base excision repair complex on abasic DNA and role of adenomatous polyposis coli on its functional activity. Biochemistry. 2011;50(11):1901-9.

58. Clarke MF, Dick JE, Dirks PB, Eaves CJ, Jamieson CH, Jones DL, et al. Cancer stem cells-perspectives on current status and future directions: AACR Workshop on cancer stem cells. Cancer research. 2006;66(19):9339-44. 
59. Eramo A, Lotti F, Sette G, Pilozzi E, Biffoni M, Di Virgilio A, et al. Identification and expansion of the tumorigenic lung cancer stem cell population. Cell death and differentiation. 2008;15(3):504-14.

60. Sarvi S, Mackinnon AC, Avlonitis N, Bradley M, Rintoul RC, Rassl DM, et al. CD133+ cancer stem-like cells in small cell lung cancer are highly tumorigenic and chemoresistant but sensitive to a novel neuropeptide antagonist. Cancer research. 2014;74(5):1554-65.

61. Yu J, Wang S, Zhao W, Duan J, Wang Z, Chen H, et al. Mechanistic Exploration of Cancer Stem Cell Marker Voltage-Dependent Calcium Channel alpha2delta1 Subunit-mediated Chemotherapy Resistance in Small-Cell Lung Cancer. Clinical cancer research : an official journal of the American Association for Cancer Research. 2018;24(9):2148-58.

62. Anastasiadou E, Jacob LS, Slack FJ. Non-coding RNA networks in cancer. Nature reviews Cancer. 2018;18(1):5-18.

63. Guil S, Esteller M. RNA-RNA interactions in gene regulation: the coding and noncoding players. Trends in biochemical sciences. 2015;40(5):248-56.

64. Wong KY, Yu L, Chim CS. DNA methylation of tumor suppressor miRNA genes: a lesson from the miR-34 family. Epigenomics. 2011;3(1):83-92.

65. Gallardo E, Navarro A, Viñolas N, Marrades RM, Diaz T, Gel B, et al. miR-34a as a prognostic marker of relapse in surgically resected non-small-cell lung cancer. Carcinogenesis. 2009;30(11):1903-9.

66. Lodygin D, Tarasov V, Epanchintsev A, Berking C, Knyazeva T, Körner H, et al. Inactivation of miR-34a by aberrant CpG methylation in multiple types of cancer. Cell cycle (Georgetown, Tex). 2008;7(16):2591-600.

67. Zenz T, Mohr J, Eldering E, Kater AP, Bühler A, Kienle D, et al. miR-34a as part of the resistance network in chronic lymphocytic leukemia. Blood. 2009;113(16):3801-8.

68. Kasinski AL, Slack FJ. miRNA-34 prevents cancer initiation and progression in a therapeutically resistant $\mathrm{K}$-ras and $\mathrm{p} 53$-induced mouse model of lung adenocarcinoma. Cancer research. 2012;72(21):5576-87.

69. Slabáková E, Culig Z, Remšík J, Souček K. Alternative mechanisms of miR-34a regulation in cancer. Cell death \& disease. 2017;8(10):e3100.

70. Hanrahan K, O'Neill A, Prencipe M, Bugler J, Murphy L, Fabre A, et al. The role of epithelialmesenchymal transition drivers ZEB1 and ZEB2 in mediating docetaxel-resistant prostate cancer. Molecular oncology. 2017;11(3):251-65.

71. Qu W, Huang W, Yang F, Ju H, Zhu G. Long noncoding RNA LINC00461 mediates cisplatin resistance of rectal cancer via miR-593-5p/CCND1 axis. Biomedicine \& pharmacotherapy = Biomedecine \& pharmacotherapie. 2020;124:109740.

72. Gao X, Zhang S, Chen Y, Wen X, Chen M, Wang S, et al. Development of a novel six-long noncoding RNA signature predicting survival of patients with bladder urothelial carcinoma. Journal of cellular biochemistry. 2019;120(12):19796-809.

73. Wang S, Xu M, Sun Z, Yu X, Deng Y, Chang H. LINC01018 confers a novel tumor suppressor role in hepatocellular carcinoma through sponging microRNA-182-5p. American journal of physiology 
Gastrointestinal and liver physiology. 2019;317(2):G116-g26.

74. Morgensztern D, Rose M, Waqar SN, Morris J, Ma PC, Reid T, et al. RRx-001 followed by platinum plus etoposide in patients with previously treated small-cell lung cancer. British journal of cancer. 2019;121(3):211-7.

75. Oronsky B, Reid TR, Larson C, Caroen S, Quinn M, Burbano E, et al. REPLATINUM Phase III randomized study: RRx-001 + platinum doublet versus platinum doublet in third-line small cell lung cancer. Future oncology (London, England). 2019;15(30):3427-33.

\section{Tables}

Table 1

Clinical characteristics of SCLC patients included in the study

\begin{tabular}{|llll|}
\hline Characteristic & $\mathbf{N}(\%)$ & Characteristic & N (\%) \\
\hline Age, mean, years & 64.2 & T stage & \\
\hline$<60$ & $1(16.7)$ & $1-2$ & $4(33.3)$ \\
\hline$\geq 60$ & $5(83.3)$ & $3-4$ & $4(66.7)$ \\
\hline Male & $6(100)$ & N stage & $2(33.3)$ \\
\hline Smoker & $6(100)$ & $0-1$ & $4(66.7)$ \\
\hline Chemotherapy & & $2-3$ & $2(33.3)$ \\
\hline Etoposide plus cisplatin & $1(16.7)$ & Metastasis & $4(66.7)$ \\
\hline Etoposide plus carboplatin & $5(83.3)$ & No & \\
\hline Response assessment & & Yes & $2(33.3)$ \\
\hline PR & $3(50.0)$ & TNM staging & $4(66.7)$ \\
\hline SD & $2(33.3)$ & III & \\
\hline PD & $1(16.7)$ & IV & \\
\hline VALSG staging & & & \\
\hline LD & $2(33.3)$ & & \\
\hline ED & $4(66.7)$ & & \\
\hline $\begin{array}{l}\text { Abbreviation: ED, extensive disease; LD, limited disease; N, Lymph Node; PD, progressive disease; PR, } \\
\text { partial response; SCLC, small cell lung cancer; SD, stable disease; T, Tumor; VALSG, Veterans }\end{array}$ & \\
\hline Administration Lung Study Group. & & & \\
\hline
\end{tabular}


Table 2

MeDIP-Seq data of clinical Samples

\begin{tabular}{|lllr|}
\hline & $\begin{array}{l}\text { Chemo-sensitive } \\
\text { group }\end{array}$ & Chemo-insensitive group & P \\
\hline Total Raw Reads, M (mean \pm SD) & $82.02 \pm 11.94$ & $83.43 \pm 1.23$ & 0.876 \\
\hline Total Clean Reads, M (mean \pm SD) & $78.18 \pm 11.26$ & $79.68 \pm 0.96$ & 0.860 \\
\hline Mapped Reads, M (mean \pm SD) & $76.32 \pm 11.32$ & $77.23 \pm 1.57$ & 0.916 \\
\hline Mapped Ratio (mean) & $97.57 \%$ & $96.91 \%$ & 0.426 \\
\hline $\begin{array}{l}\text { Unique Mapped Reads, M (mean } \pm \\
\text { SD) }\end{array}$ & $47.25 \pm 5.54$ & $49.47 \pm 2.43$ & 0.631 \\
\hline Unique Mapped Ratio (mean) & $60.68 \%$ & $62.12 \%$ & 0.658 \\
\hline $\begin{array}{l}\text { Abbreviation: MeDIP-Seq, methylated DNA immunoprecipitation sequencing; M, millions; SD, standard } \\
\text { deviation; PR, partial response; PD, progressive disease; SD, stable disease; P, P value for whole. }\end{array}$ \\
\hline
\end{tabular}

Table 3

The top5 enriched GO terms of DMGs.

\begin{tabular}{|llll|}
\hline GO ID & Term & Count & P \\
\hline G0:0007517 & muscle organ development & 25 & $\begin{array}{l}1.07 \times \\
10^{-6}\end{array}$ \\
\hline G0:0060537 & muscle tissue development & 25 & $\begin{array}{l}7.50 \times \\
10^{-6}\end{array}$ \\
\hline G0:0014706 & striated muscle tissue development & 22 & $1.29 \times$ \\
& & 23 & $10^{-5}$ \\
\hline G0:0097060 & synaptic membrane & $3.66 \times$ \\
& & 23 & $10^{-5}$ \\
\hline G0:0001228 & $\begin{array}{l}\text { DNA-binding transcription activator activity, RNA polymerase II- } \\
\text { specific }\end{array}$ & $23 \times$ \\
\hline $\begin{array}{l}\text { Abbreviation: Count, the number of DMGs participated in the corresponding GO term; DMGs, } \\
\text { differentially methylated genes; GO, Gene Ontology; } P \text {, P value for whole. }\end{array}$ \\
\hline Statistically significant data were marked with bold and underline. & & \\
\hline
\end{tabular}


Table 4

The top5 enriched KEGG pathways of DMGs

\begin{tabular}{|llll|}
\hline KEGG ID & Pathway name & Count & P \\
\hline hsa04310 & Wnt signaling pathway & 11 & $1.32 \times 10^{-3}$ \\
\hline hsa04550 & Signaling pathways regulating pluripotency of stem cells & 10 & $1.63 \times 10^{-3}$ \\
\hline hsa00564 & Glycerophospholipid metabolism & 8 & $2.06 \times 10^{-3}$ \\
\hline hsa04721 & Synaptic vesicle cycle & 7 & $2.27 \times 10^{-3}$ \\
\hline hsa00561 & Glycerolipid metabolism & 6 & $2.93 \times 10^{-3}$ \\
\hline $\begin{array}{l}\text { Abbreviation: } \text { Count, the number of DMGs participated in the corresponding pathway; DMGs, } \\
\text { differentially methylated genes; KEGG, Kyoto Encyclopedia of Genes and Genomes; P,P value for } \\
\text { whole. }\end{array}$ & & \\
\hline \begin{tabular}{l} 
Statistically significant data were marked with bold and underline. \\
\hline
\end{tabular}
\end{tabular}


Table 5

The top 10 hypermethylated and hypomethylated protein-coding genes showing differential expression in SCLC chemo-insensitive tissues compared with chemo-sensitive tissues.

\begin{tabular}{|c|c|c|c|c|c|c|}
\hline \multirow{2}{*}{$\begin{array}{l}\text { Gene } \\
\text { symbol }\end{array}$} & \multicolumn{2}{|c|}{ RPKM (mean \pm SD) } & \multirow{2}{*}{$\begin{array}{l}\text { Mean fold change } \\
\text { (chemo- } \\
\text { insensitive/sensitive } \\
\text { group) }\end{array}$} & \multirow[t]{2}{*}{$\mathbf{P}$} & \multirow{2}{*}{$\begin{array}{l}\text { Methylation } \\
\text { status }\end{array}$} & \multirow{2}{*}{$\begin{array}{l}\text { Coding } \\
\text { gene } \\
\text { expression }\end{array}$} \\
\hline & $\begin{array}{l}\text { chemo- } \\
\text { insensitive } \\
\text { group }\end{array}$ & $\begin{array}{l}\text { Chemo- } \\
\text { sensitive } \\
\text { group }\end{array}$ & & & & \\
\hline \multirow[t]{2}{*}{ APBB1IP } & $\begin{array}{l}18.91 \pm \\
3.52\end{array}$ & $\begin{array}{l}0.47 \pm \\
0.33\end{array}$ & 572.05 & $\begin{array}{l}7.02 \\
\times\end{array}$ & Up & Down \\
\hline & & & & $\begin{array}{l}10^{-} \\
20\end{array}$ & & \\
\hline \multirow[t]{2}{*}{ ZNF529 } & $\begin{array}{l}6.70 \pm \\
2.41\end{array}$ & $\begin{array}{l}0.06 \pm \\
0.02\end{array}$ & 786.88 & $\begin{array}{l}8.51 \\
\times\end{array}$ & Up & Down \\
\hline & & & & $\begin{array}{l}10^{-} \\
20\end{array}$ & & \\
\hline \multirow[t]{2}{*}{ TP53TG3D } & $\begin{array}{l}15.60 \pm \\
3.73\end{array}$ & $\begin{array}{l}0.44 \pm \\
0.45\end{array}$ & 418.77 & $\begin{array}{l}1.03 \\
\times\end{array}$ & Up & Down \\
\hline & & & & $\begin{array}{l}10^{-} \\
19\end{array}$ & & \\
\hline \multirow[t]{2}{*}{ CELF2 } & $\begin{array}{l}8.03 \pm \\
1.16\end{array}$ & $\begin{array}{l}0.05 \pm \\
0.04\end{array}$ & 568.10 & $\begin{array}{l}1.37 \\
\times\end{array}$ & Up & Down \\
\hline & & & & $\begin{array}{l}10^{-} \\
19\end{array}$ & & \\
\hline \multirow[t]{2}{*}{ CRMP1 } & $\begin{array}{l}10.12 \pm \\
4.80\end{array}$ & $\begin{array}{l}0.13 \pm \\
0.13\end{array}$ & 173.65 & $\begin{array}{l}1.29 \\
\times\end{array}$ & Up & Down \\
\hline & & & & $\begin{array}{l}10^{-} \\
18\end{array}$ & & \\
\hline \multirow[t]{2}{*}{ RNF223 } & $\begin{array}{l}5.76 \pm \\
1.22\end{array}$ & $\begin{array}{l}0.42 \pm \\
0.35\end{array}$ & 302.33 & $\begin{array}{l}1.04 \\
\times\end{array}$ & Up & Down \\
\hline & & & & $\begin{array}{l}10^{-} \\
17\end{array}$ & & \\
\hline \multirow[t]{2}{*}{ BTBD11 } & $\begin{array}{l}5.12 \pm \\
1.18\end{array}$ & $\begin{array}{l}0.50 \pm \\
0.28\end{array}$ & 227.54 & $\begin{array}{l}1.18 \\
\times\end{array}$ & Up & Down \\
\hline & & & & $\begin{array}{l}10^{-} \\
17\end{array}$ & & \\
\hline \multirow[t]{2}{*}{ SYNE1 } & $\begin{array}{l}8.96 \pm \\
1.94\end{array}$ & $\begin{array}{l}0.02 \pm \\
0.02\end{array}$ & 308.69 & $\begin{array}{l}1.21 \\
\times\end{array}$ & Up & Down \\
\hline & & & & $\begin{array}{l}10^{-} \\
17\end{array}$ & & \\
\hline \multicolumn{7}{|c|}{$\begin{array}{l}\text { Abbreviation: RPKM, reads per kilobase per million; SD, standard deviation; SCLC, small cell lung } \\
\text { cancer; P, P value for whole. }\end{array}$} \\
\hline
\end{tabular}




\begin{tabular}{|c|c|c|c|c|c|c|}
\hline \multirow{2}{*}{$\begin{array}{l}\text { Gene } \\
\text { symbol }\end{array}$} & \multicolumn{2}{|c|}{ RPKM (mean \pm SD) } & \multirow{2}{*}{$\begin{array}{l}\text { Mean fold change } \\
\text { (chemo- } \\
\text { insensitive/sensitive } \\
\text { group) }\end{array}$} & \multirow[t]{2}{*}{$\mathbf{P}$} & \multirow{2}{*}{$\begin{array}{l}\text { Methylation } \\
\text { status }\end{array}$} & \multirow{2}{*}{$\begin{array}{l}\text { Coding } \\
\text { gene } \\
\text { expression }\end{array}$} \\
\hline & $\begin{array}{l}\text { chemo- } \\
\text { insensitive } \\
\text { group }\end{array}$ & $\begin{array}{l}\text { Chemo- } \\
\text { sensitive } \\
\text { group }\end{array}$ & & & & \\
\hline \multirow[t]{2}{*}{ TSPAN4 } & $\begin{array}{l}8.26 \pm \\
5.06\end{array}$ & $\begin{array}{l}0.21 \pm \\
0.10\end{array}$ & 1184.45 & $\begin{array}{l}1.44 \\
\times\end{array}$ & Up & Down \\
\hline & & & & $\begin{array}{l}10^{-} \\
17\end{array}$ & & \\
\hline \multirow[t]{2}{*}{ VILL } & $\begin{array}{l}7.75 \pm \\
0.86\end{array}$ & $\begin{array}{l}0.52 \pm \\
0.55\end{array}$ & 95.01 & $\begin{array}{l}6.46 \\
\times\end{array}$ & Up & Down \\
\hline & & & & $\begin{array}{l}10^{-} \\
17\end{array}$ & & \\
\hline \multirow[t]{2}{*}{ NRG2 } & $\begin{array}{l}0.58 \pm \\
0.39\end{array}$ & $\begin{array}{l}15.91 \pm \\
0.97\end{array}$ & -487.75 & $\begin{array}{l}1.84 \\
\times\end{array}$ & Down & Up \\
\hline & & & & $\begin{array}{l}10^{-} \\
36\end{array}$ & & \\
\hline \multirow[t]{2}{*}{ RYR2 } & $\begin{array}{l}0.18 \pm \\
0.09\end{array}$ & $\begin{array}{l}7.07 \pm \\
2.23\end{array}$ & -1176.27 & $\begin{array}{l}3.74 \\
\times\end{array}$ & Down & Up \\
\hline & & & & $\begin{array}{l}10^{-} \\
28\end{array}$ & & \\
\hline \multirow[t]{2}{*}{ WNT10A } & $\begin{array}{l}0.26 \pm \\
0.30\end{array}$ & $\begin{array}{l}7.32 \pm \\
0.76\end{array}$ & -849.22 & $\begin{array}{l}8.29 \\
\times\end{array}$ & Down & Up \\
\hline & & & & $\begin{array}{l}10^{-} \\
26\end{array}$ & & \\
\hline \multirow[t]{2}{*}{ FAM135B } & $\begin{array}{l}0.49 \pm \\
0.10\end{array}$ & $\begin{array}{l}5.83 \pm \\
2.03\end{array}$ & -792.35 & $\begin{array}{l}8.65 \\
\times\end{array}$ & Down & Up \\
\hline & & & & $\begin{array}{l}10^{-} \\
25\end{array}$ & & \\
\hline \multirow[t]{2}{*}{ PON3 } & $\begin{array}{l}0.35 \pm \\
0.20\end{array}$ & $\begin{array}{l}6.49 \pm \\
0.39\end{array}$ & -504.95 & $\begin{array}{l}3.82 \\
\times\end{array}$ & Down & Up \\
\hline & & & & $\begin{array}{l}10^{-} \\
23\end{array}$ & & \\
\hline \multirow[t]{2}{*}{ KBTBD12 } & $\begin{array}{l}0.32 \pm \\
0.22\end{array}$ & $\begin{array}{l}4.56 \pm \\
1.39\end{array}$ & -382.68 & $\begin{array}{l}2.99 \\
\times\end{array}$ & Down & Up \\
\hline & & & & $\begin{array}{l}10^{-} \\
20\end{array}$ & & \\
\hline
\end{tabular}

Abbreviation: RPKM, reads per kilobase per million; SD, standard deviation; SCLC, small cell lung cancer; $P, P$ value for whole.

Statistically significant data were marked with bold and underline. 


\begin{tabular}{|c|c|c|c|c|c|c|}
\hline \multirow{2}{*}{$\begin{array}{l}\text { Gene } \\
\text { symbol }\end{array}$} & \multicolumn{2}{|c|}{$\mathrm{RPKM}($ mean $\pm \mathrm{SD})$} & \multirow{2}{*}{$\begin{array}{l}\text { Mean fold change } \\
\text { (chemo- } \\
\text { insensitive/sensitive } \\
\text { group) }\end{array}$} & \multirow[t]{2}{*}{$\mathbf{P}$} & \multirow{2}{*}{$\begin{array}{l}\text { Methylation } \\
\text { status }\end{array}$} & \multirow{2}{*}{$\begin{array}{l}\text { Coding } \\
\text { gene } \\
\text { expression }\end{array}$} \\
\hline & $\begin{array}{l}\text { chemo- } \\
\text { insensitive } \\
\text { group }\end{array}$ & $\begin{array}{l}\text { Chemo- } \\
\text { sensitive } \\
\text { group }\end{array}$ & & & & \\
\hline \multirow[t]{2}{*}{ NRG3 } & $\begin{array}{l}0.82 \pm \\
0.29\end{array}$ & $\begin{array}{l}5.66 \pm \\
4.65\end{array}$ & -508.46 & $\begin{array}{l}5.29 \\
\times\end{array}$ & Down & Up \\
\hline & & & & $\begin{array}{l}10^{-} \\
20\end{array}$ & & \\
\hline \multirow[t]{2}{*}{ CHRM3 } & $\begin{array}{l}0.10 \pm \\
0.07\end{array}$ & $\begin{array}{l}4.89 \pm \\
2.23\end{array}$ & -694.58 & $\begin{array}{l}6.40 \\
\times\end{array}$ & Down & Up \\
\hline & & & & $\begin{array}{l}10^{-} \\
20\end{array}$ & & \\
\hline \multirow[t]{2}{*}{ SLC6A11 } & $\begin{array}{l}0.46 \pm \\
0.30\end{array}$ & $\begin{array}{l}5.89 \pm \\
1.57\end{array}$ & -436.55 & $\begin{array}{l}7.33 \\
\times\end{array}$ & Down & Up \\
\hline & & & & $\begin{array}{l}10^{-} \\
20\end{array}$ & & \\
\hline \multirow[t]{2}{*}{ RIMS1 } & $\begin{array}{l}0.44 \pm \\
0.26\end{array}$ & $\begin{array}{l}9.30 \pm \\
4.07\end{array}$ & -424.61 & $\begin{array}{l}3.06 \\
\times\end{array}$ & Down & Up \\
\hline & & & & $\begin{array}{l}10^{-} \\
18\end{array}$ & & \\
\hline \multicolumn{7}{|c|}{$\begin{array}{l}\text { Abbreviation: RPKM, reads per kilobase per million; SD, standard deviation; SCLC, small cell lung } \\
\text { cancer; } P \text {, P value for whole. }\end{array}$} \\
\hline
\end{tabular}


Table 6

The top 10 hyper- and hypo- methylated miRNAs expressed differentially in SCLC chemo-insensitive tissues compared with chemo-sensitive tissues

\begin{tabular}{|c|c|c|c|c|c|c|}
\hline \multirow{2}{*}{$\begin{array}{l}\text { Gene } \\
\text { symbol }\end{array}$} & \multicolumn{2}{|c|}{ RPKM (mean \pm SD) } & \multirow{2}{*}{$\begin{array}{l}\text { Mean fold change } \\
\text { (chemo- } \\
\text { insensitive/sensitive } \\
\text { group) }\end{array}$} & \multirow[t]{2}{*}{$\mathbf{P}$} & \multirow{2}{*}{$\begin{array}{l}\text { Methylation } \\
\text { status }\end{array}$} & \multirow{2}{*}{$\begin{array}{l}\text { miRNA } \\
\text { expression } \\
\text { level }\end{array}$} \\
\hline & $\begin{array}{l}\text { chemo- } \\
\text { insensitive } \\
\text { group }\end{array}$ & $\begin{array}{l}\text { Chemo- } \\
\text { sensitive } \\
\text { group }\end{array}$ & & & & \\
\hline \multirow[t]{2}{*}{ MIR320D1 } & $\begin{array}{l}4.78 \pm \\
2.16\end{array}$ & $\begin{array}{l}0.46 \pm \\
0.38\end{array}$ & 83.29 & $\begin{array}{l}2.94 \\
\times\end{array}$ & Up & Down \\
\hline & & & & $\begin{array}{l}10^{-} \\
10\end{array}$ & & \\
\hline \multirow[t]{2}{*}{ MIR4641 } & $\begin{array}{l}4.03 \pm \\
2.95\end{array}$ & $\begin{array}{l}0.36 \pm \\
0.26\end{array}$ & 430.54 & $\begin{array}{l}3.99 \\
\times\end{array}$ & Up & Down \\
\hline & & & & $\begin{array}{l}10^{-} \\
10\end{array}$ & & \\
\hline MIR133A2 & $\begin{array}{l}2.14 \pm \\
1.04\end{array}$ & $\begin{array}{l}0.33 \pm \\
0.10\end{array}$ & 82.71 & $\begin{array}{l}3.87 \\
\times \\
10^{-6}\end{array}$ & Up & Down \\
\hline MIR6742 & $\begin{array}{l}21.41 \pm \\
2.63\end{array}$ & $\begin{array}{l}4.47 \pm \\
4.91\end{array}$ & 26.54 & $\begin{array}{l}4.63 \\
\times \\
10^{-6}\end{array}$ & Up & Down \\
\hline MIR4666A & $\begin{array}{l}3.50 \pm \\
2.74\end{array}$ & $\begin{array}{l}0.02 \pm \\
0.01\end{array}$ & 292.04 & $\begin{array}{l}1.26 \\
\times \\
10^{-5}\end{array}$ & Up & Down \\
\hline MIR148A & $\begin{array}{l}3.43 \pm \\
2.31\end{array}$ & $\begin{array}{l}0.33 \pm \\
0.34\end{array}$ & 44.02 & $\begin{array}{l}1.2 \\
\times \\
10^{-4}\end{array}$ & Up & Down \\
\hline MIR1973 & $\begin{array}{l}24.79 \pm \\
1.33\end{array}$ & $\begin{array}{l}3.00 \pm \\
3.04\end{array}$ & 27.28 & $\begin{array}{l}4.04 \\
\times \\
10^{-4}\end{array}$ & Up & Down \\
\hline MIR1469 & $\begin{array}{l}7.00 \pm \\
2.30\end{array}$ & $\begin{array}{l}2.64 \pm \\
0.60\end{array}$ & 3.46 & $\begin{array}{l}4.76 \\
\times \\
10^{-3}\end{array}$ & Up & Down \\
\hline MIR1267 & $\begin{array}{l}7.72 \pm \\
3.99\end{array}$ & $\begin{array}{l}3.98 \pm \\
2.70\end{array}$ & 4.86 & $\begin{array}{l}5.36 \\
\times \\
10^{-3}\end{array}$ & Up & Down \\
\hline
\end{tabular}

Abbreviation: miRNAs, microRNAs; RPKM, reads per kilobase per million; SD, standard deviation; SCLC, small cell lung cancer; P, P value for whole.

Statistically significant data were marked with bold and underline. 


\begin{tabular}{|c|c|c|c|c|c|c|}
\hline \multirow{2}{*}{$\begin{array}{l}\text { Gene } \\
\text { symbol }\end{array}$} & \multicolumn{2}{|c|}{ RPKM (mean \pm SD) } & \multirow{2}{*}{$\begin{array}{l}\text { Mean fold change } \\
\text { (chemo- } \\
\text { insensitive/sensitive } \\
\text { group) }\end{array}$} & \multirow[t]{2}{*}{$P$} & \multirow{2}{*}{$\begin{array}{l}\text { Methylation } \\
\text { status }\end{array}$} & \multirow{2}{*}{$\begin{array}{l}\text { miRNA } \\
\text { expression } \\
\text { level }\end{array}$} \\
\hline & $\begin{array}{l}\text { chemo- } \\
\text { insensitive } \\
\text { group }\end{array}$ & $\begin{array}{l}\text { Chemo- } \\
\text { sensitive } \\
\text { group }\end{array}$ & & & & \\
\hline MIR1247 & $\begin{array}{l}8.48 \pm \\
3.81\end{array}$ & $\begin{array}{l}2.75 \pm \\
2.22\end{array}$ & 4.11 & $\begin{array}{l}7.74 \\
\times \\
10^{-3}\end{array}$ & Up & Down \\
\hline MIR4478 & $\begin{array}{l}0.23 \pm \\
0.10\end{array}$ & $\begin{array}{l}8.47 \pm \\
6.37\end{array}$ & -837.53 & $\begin{array}{l}1.74 \\
\times \\
10^{-} \\
11\end{array}$ & Down & Up \\
\hline MIR365B & $\begin{array}{l}2.20 \pm \\
0.21\end{array}$ & $\begin{array}{l}3.02 \pm \\
0.62\end{array}$ & -2.97 & $\begin{array}{l}3.13 \\
\times \\
10^{-5}\end{array}$ & Down & Up \\
\hline MIR378C & $\begin{array}{l}2.28 \pm \\
1.00\end{array}$ & $\begin{array}{l}3.11 \pm \\
0.28\end{array}$ & -4.92 & $\begin{array}{l}7.87 \\
\times \\
10^{-5}\end{array}$ & Down & Up \\
\hline MIR589 & $\begin{array}{l}1.66 \pm \\
0.31\end{array}$ & $\begin{array}{l}2.46 \pm \\
0.57\end{array}$ & -3.25 & $\begin{array}{l}2.08 \\
\times \\
10^{-4}\end{array}$ & Down & Up \\
\hline MIR4438 & $\begin{array}{l}1.72 \pm \\
0.54\end{array}$ & $\begin{array}{l}3.09 \pm \\
0.63\end{array}$ & -5.24 & $\begin{array}{l}4.21 \\
\times \\
10^{-4}\end{array}$ & Down & Up \\
\hline MIR4798 & $\begin{array}{l}2.33 \pm \\
0.25\end{array}$ & $\begin{array}{l}3.89 \pm \\
1.70\end{array}$ & -2.43 & $\begin{array}{l}1.32 \\
\times \\
10^{-3}\end{array}$ & Down & Up \\
\hline MIR150 & $\begin{array}{l}2.03 \pm \\
0.35\end{array}$ & $\begin{array}{l}3.40 \pm \\
0.38\end{array}$ & -2.93 & $\begin{array}{l}1.46 \\
\times \\
10^{-3}\end{array}$ & Down & Up \\
\hline MIR8062 & $\begin{array}{l}2.02 \pm \\
0.53\end{array}$ & $\begin{array}{l}5.46 \pm \\
3.21\end{array}$ & -4.00 & $\begin{array}{l}2.87 \\
\times \\
10^{-3}\end{array}$ & Down & Up \\
\hline MIR34A & $\begin{array}{l}2.11 \pm \\
0.32\end{array}$ & $\begin{array}{l}3.12 \pm \\
0.42\end{array}$ & -2.81 & $\begin{array}{l}3.20 \\
\times \\
10^{-3}\end{array}$ & Down & Up \\
\hline
\end{tabular}

Abbreviation: miRNAs, microRNAs; RPKM, reads per kilobase per million; SD, standard deviation; SCLC, small cell lung cancer; $P, P$ value for whole.

Statistically significant data were marked with bold and underline. 


\begin{tabular}{|c|c|c|c|c|c|c|}
\hline \multirow{2}{*}{$\begin{array}{l}\text { Gene } \\
\text { symbol }\end{array}$} & \multicolumn{2}{|c|}{ RPKM (mean \pm SD) } & \multirow{2}{*}{$\begin{array}{l}\text { Mean fold change } \\
\text { (chemo- } \\
\text { insensitive/sensitive } \\
\text { group) }\end{array}$} & \multirow[t]{2}{*}{$P$} & \multirow{2}{*}{$\begin{array}{l}\text { Methylation } \\
\text { status }\end{array}$} & \multirow{2}{*}{$\begin{array}{l}\text { miRNA } \\
\text { expression } \\
\text { level }\end{array}$} \\
\hline & $\begin{array}{l}\text { chemo- } \\
\text { insensitive } \\
\text { group }\end{array}$ & $\begin{array}{l}\text { Chemo- } \\
\text { sensitive } \\
\text { group }\end{array}$ & & & & \\
\hline MIR1269A & $\begin{array}{l}5.34 \pm \\
1.67\end{array}$ & $\begin{array}{l}10.57 \pm \\
4.93\end{array}$ & -2.45 & $\begin{array}{l}4.14 \\
\times \\
10^{-3}\end{array}$ & Down & Up \\
\hline \multicolumn{7}{|c|}{$\begin{array}{l}\text { Abbreviation: miRNAs, microRNAs; RPKM, reads per kilobase per million; SD, standard deviation; } \\
\text { SCLC, small cell lung cancer; P, P value for whole. }\end{array}$} \\
\hline \multicolumn{7}{|c|}{ Statistically significant data were marked with bold and underline. } \\
\hline
\end{tabular}


Table 7

The top 10 hyper- and hypo- methylated IncRNAs expressed differentially in chemo-insensitive tissues compared with chemo-sensitive tissues

\begin{tabular}{|c|c|c|c|c|c|c|}
\hline \multirow{2}{*}{$\begin{array}{l}\text { Gene } \\
\text { symbol }\end{array}$} & \multicolumn{2}{|c|}{ RPKM (mean \pm SD) } & \multirow{2}{*}{$\begin{array}{l}\text { Mean fold change } \\
\text { (chemo- } \\
\text { insensitive/sensitive } \\
\text { group) }\end{array}$} & \multirow[t]{2}{*}{$\mathbf{P}$} & \multirow{2}{*}{$\begin{array}{l}\text { Methylation } \\
\text { status }\end{array}$} & \multirow{2}{*}{$\begin{array}{l}\text { IncRNA } \\
\text { expression } \\
\text { level }\end{array}$} \\
\hline & $\begin{array}{l}\text { chemo- } \\
\text { insensitive } \\
\text { group }\end{array}$ & $\begin{array}{l}\text { Chemo- } \\
\text { sensitive } \\
\text { group }\end{array}$ & & & & \\
\hline \multirow[t]{2}{*}{ H1FX-AS1 } & $\begin{array}{l}7.29 \pm \\
2.04\end{array}$ & $\begin{array}{l}0.41 \pm \\
0.44\end{array}$ & 205.07 & $\begin{array}{l}2.12 \\
\times\end{array}$ & Up & Down \\
\hline & & & & $\begin{array}{l}10^{-} \\
14\end{array}$ & & \\
\hline \multirow[t]{2}{*}{ LINC00354 } & $\begin{array}{l}3.18 \pm \\
1.21\end{array}$ & $\begin{array}{l}0.68 \pm \\
0.42\end{array}$ & 63.12 & $\begin{array}{l}2.18 \\
\times\end{array}$ & Up & Down \\
\hline & & & & $\begin{array}{l}10^{-} \\
11\end{array}$ & & \\
\hline CATIP-AS1 & $\begin{array}{l}8.17 \pm \\
2.21\end{array}$ & $\begin{array}{l}1.34 \pm \\
0.23\end{array}$ & 7.73 & $\begin{array}{l}1.12 \\
\times \\
10^{-8}\end{array}$ & Up & Down \\
\hline LINC02119 & $\begin{array}{l}3.69 \pm \\
1.42\end{array}$ & $\begin{array}{l}0.40 \pm \\
0.19\end{array}$ & 54.57 & $\begin{array}{l}2.83 \\
\times \\
10^{-8}\end{array}$ & Up & Down \\
\hline LINC01192 & $\begin{array}{l}3.73 \pm \\
2.19\end{array}$ & $\begin{array}{l}1.00 \pm \\
0.00\end{array}$ & 49.87 & $\begin{array}{l}6.09 \\
\times \\
10^{-5}\end{array}$ & Up & Down \\
\hline LINC01018 & $\begin{array}{l}1.64 \pm \\
0.93\end{array}$ & $\begin{array}{l}0.59 \pm \\
0.23\end{array}$ & 38.59 & $\begin{array}{l}8.65 \\
\times \\
10^{-5}\end{array}$ & Up & Down \\
\hline LINC01168 & $\begin{array}{l}2.67 \pm \\
1.77\end{array}$ & $\begin{array}{l}0.11 \pm \\
0.06\end{array}$ & 43.41 & $\begin{array}{l}1.19 \\
\times \\
10^{-4}\end{array}$ & Up & Down \\
\hline $\begin{array}{l}\text { RDH10- } \\
\text { AS1 }\end{array}$ & $\begin{array}{l}2.82 \pm \\
1.88\end{array}$ & $\begin{array}{l}0.38 \pm \\
0.47\end{array}$ & 41.36 & $\begin{array}{l}1.79 \\
\times \\
10^{-4}\end{array}$ & Up & Down \\
\hline LINC01194 & $\begin{array}{l}4.37 \pm \\
0.85\end{array}$ & $\begin{array}{l}0.75 \pm \\
0.41\end{array}$ & 9.85 & $\begin{array}{l}5.73 \\
\times \\
10^{-4}\end{array}$ & Up & Down \\
\hline
\end{tabular}

Abbreviation: IncRNAs, long non-coding RNAs; RPKM, reads per kilobase per million; SD, standard deviation; SCLC, small cell lung cancer; P, P value for whole.

Statistically significant data were marked with bold and underline. 


\begin{tabular}{|c|c|c|c|c|c|c|}
\hline \multirow{2}{*}{$\begin{array}{l}\text { Gene } \\
\text { symbol }\end{array}$} & \multicolumn{2}{|c|}{ RPKM (mean \pm SD) } & \multirow{2}{*}{$\begin{array}{l}\text { Mean fold change } \\
\text { (chemo- } \\
\text { insensitive/sensitive } \\
\text { group) }\end{array}$} & \multirow[t]{2}{*}{$\mathbf{P}$} & \multirow{2}{*}{$\begin{array}{l}\text { Methylation } \\
\text { status }\end{array}$} & \multirow{2}{*}{$\begin{array}{l}\text { IncRNA } \\
\text { expression } \\
\text { level }\end{array}$} \\
\hline & $\begin{array}{l}\text { chemo- } \\
\text { insensitive } \\
\text { group }\end{array}$ & $\begin{array}{l}\text { Chemo- } \\
\text { sensitive } \\
\text { group }\end{array}$ & & & & \\
\hline LINC00469 & $\begin{array}{l}4.72 \pm \\
0.56\end{array}$ & $\begin{array}{l}1.90 \pm \\
0.19\end{array}$ & 3.32 & $\begin{array}{l}1.23 \\
\times \\
10^{-3}\end{array}$ & Up & Down \\
\hline LINC02298 & $\begin{array}{l}0.41 \pm \\
0.31\end{array}$ & $\begin{array}{l}3.54 \pm \\
2.65\end{array}$ & -484.38 & $\begin{array}{l}2.58 \\
\times \\
10^{-} \\
10\end{array}$ & Down & Up \\
\hline LINC01435 & $\begin{array}{l}0.98 \pm \\
0.31\end{array}$ & $\begin{array}{l}3.17 \pm \\
1.25\end{array}$ & -28.84 & $\begin{array}{l}1.89 \\
\times \\
10^{-8}\end{array}$ & Down & Up \\
\hline LINC01264 & $\begin{array}{l}0.82 \pm \\
0.09\end{array}$ & $\begin{array}{l}2.42 \pm \\
1.26\end{array}$ & -125.37 & $\begin{array}{l}3.18 \\
\times \\
10^{-7}\end{array}$ & Down & Up \\
\hline LINC01968 & $\begin{array}{l}1.79 \pm \\
0.14\end{array}$ & $\begin{array}{l}2.31 \pm \\
0.15\end{array}$ & -3.16 & $\begin{array}{l}1.70 \\
\times \\
10^{-6}\end{array}$ & Down & Up \\
\hline LINC01121 & $\begin{array}{l}3.18 \pm \\
2.20\end{array}$ & $\begin{array}{l}6.00 \pm \\
0.59\end{array}$ & -6.36 & $\begin{array}{l}3.42 \\
\times \\
10^{-6}\end{array}$ & Down & Up \\
\hline LINC01484 & $\begin{array}{l}1.61 \pm \\
0.19\end{array}$ & $\begin{array}{l}6.24 \pm \\
0.92\end{array}$ & -7.31 & $\begin{array}{l}4.17 \\
\times \\
10^{-6}\end{array}$ & Down & Up \\
\hline LINC01565 & $\begin{array}{l}1.93 \pm \\
0.20\end{array}$ & $\begin{array}{l}4.25 \pm \\
0.81\end{array}$ & -3.58 & $\begin{array}{l}1.30 \\
\times \\
10^{-5}\end{array}$ & Down & Up \\
\hline LINC01006 & $\begin{array}{l}8.30 \pm \\
3.93\end{array}$ & $\begin{array}{l}12.83 \pm \\
1.28\end{array}$ & -3.68 & $\begin{array}{l}1.77 \\
\times \\
10^{-5}\end{array}$ & Down & Up \\
\hline LINC00461 & $\begin{array}{l}0.08 \pm \\
0.05\end{array}$ & $\begin{array}{l}3.56 \pm \\
3.81\end{array}$ & -442.64 & $\begin{array}{l}2.59 \\
\times \\
10^{-5}\end{array}$ & Down & Up \\
\hline
\end{tabular}

Abbreviation: IncRNAs, long non-coding RNAs; RPKM, reads per kilobase per million; SD, standard deviation; SCLC, small cell lung cancer; P, P value for whole.

Statistically significant data were marked with bold and underline. 


\begin{tabular}{|c|c|c|c|c|c|c|}
\hline \multirow{2}{*}{$\begin{array}{l}\text { Gene } \\
\text { symbol }\end{array}$} & \multicolumn{2}{|c|}{ RPKM (mean \pm SD) } & \multirow{2}{*}{$\begin{array}{l}\text { Mean fold change } \\
\text { (chemo- } \\
\text { insensitive/sensitive } \\
\text { group) }\end{array}$} & \multirow[t]{2}{*}{$\mathbf{P}$} & \multirow{2}{*}{$\begin{array}{l}\text { Methylation } \\
\text { status }\end{array}$} & \multirow{2}{*}{$\begin{array}{l}\text { IncRNA } \\
\text { expression } \\
\text { level }\end{array}$} \\
\hline & $\begin{array}{l}\text { chemo- } \\
\text { insensitive } \\
\text { group }\end{array}$ & $\begin{array}{l}\text { Chemo- } \\
\text { sensitive } \\
\text { group }\end{array}$ & & & & \\
\hline LINC01143 & $\begin{array}{l}1.80 \pm \\
0.64\end{array}$ & $\begin{array}{l}2.45 \pm \\
0.56\end{array}$ & -4.82 & $\begin{array}{l}3.03 \\
x \\
10^{-5}\end{array}$ & Down & Up \\
\hline \multicolumn{7}{|c|}{$\begin{array}{l}\text { Abbreviation: IncRNAs, long non-coding RNAs; RPKM, reads per kilobase per million; SD, standard } \\
\text { deviation; SCLC, small cell lung cancer; P, P value for whole. }\end{array}$} \\
\hline
\end{tabular}

\section{Figures}
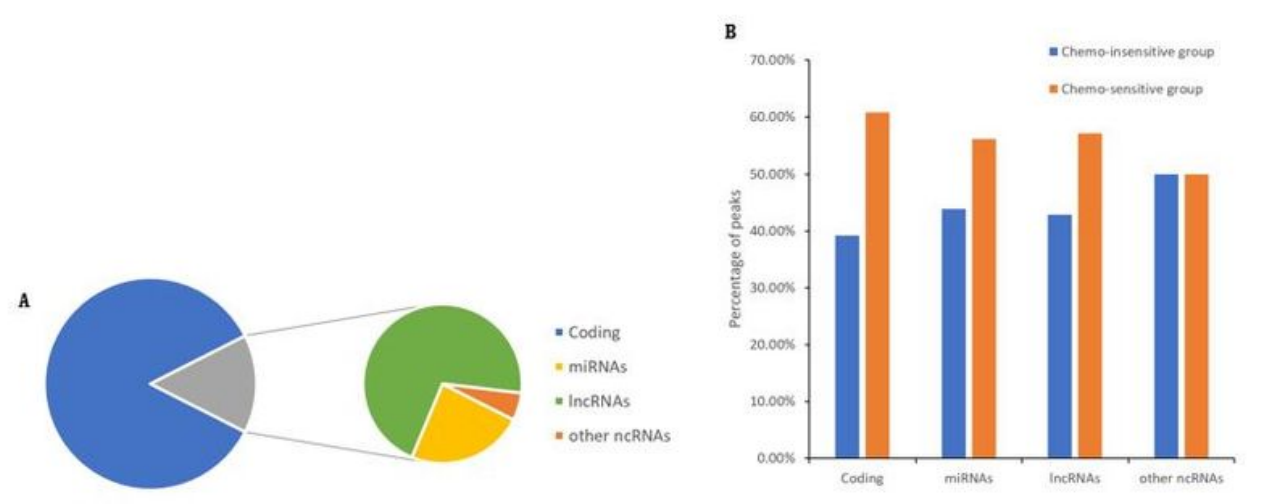

c
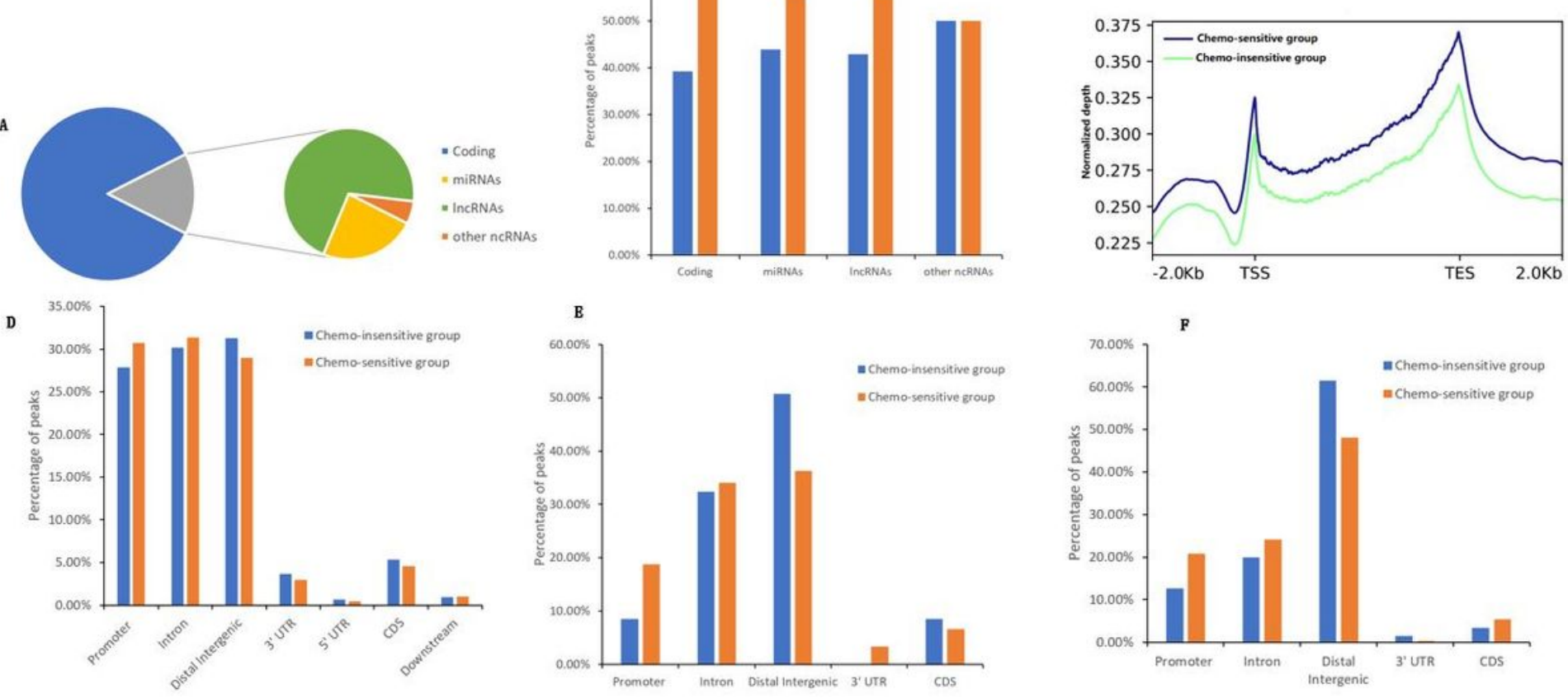

Figure 1

DMGs profile and methylation enrichment distribution. A) The proportion of coning and non-coding RNAs in all DMGs. Of 4552 DMGs were selected (fold change $\geq 2, p<0.01$ ), coding genes constituted the largest percentage ( $85.08 \%)$, followed by IncRNAs (10.52\%) and miRNAs (3.56\%). B) The distribution of differentially hypermethylated genes in the chemo-insensitive and chemo-sensitive group. C) Distribution of reads obtained by MeDIP-seq in the intragenic gene region, and regions $2 \mathrm{~kb}$ upstream and downstream $2 \mathrm{~kb}$ of the genes. D) Among differentially methylated protein-coding genes in two groups, the proportion of methylation enrichment in the promoter region, the intron region, and the distal intergenic region was around $30 \%$. E-F) The methylation enrichment of all differentially methylated 
miRNAs and IncRNAs. The distal intergenic region shared the highest enrichment of methylation in both IncRNAs and miRNAs. Abbreviation: DMGs, differentially methylated genes; IncRNAs, long non-coding RNAs; miRNAs, microRNAs; ncRNAs, non-coding RNAs; TSS, transcription start site; TES, transcription end site; $-2 \mathrm{~kb}, 2 \mathrm{~kb}$ r egion upstream of the TSS; $+2 \mathrm{~kb}, 2 \mathrm{~kb}$ region downstream of TES.

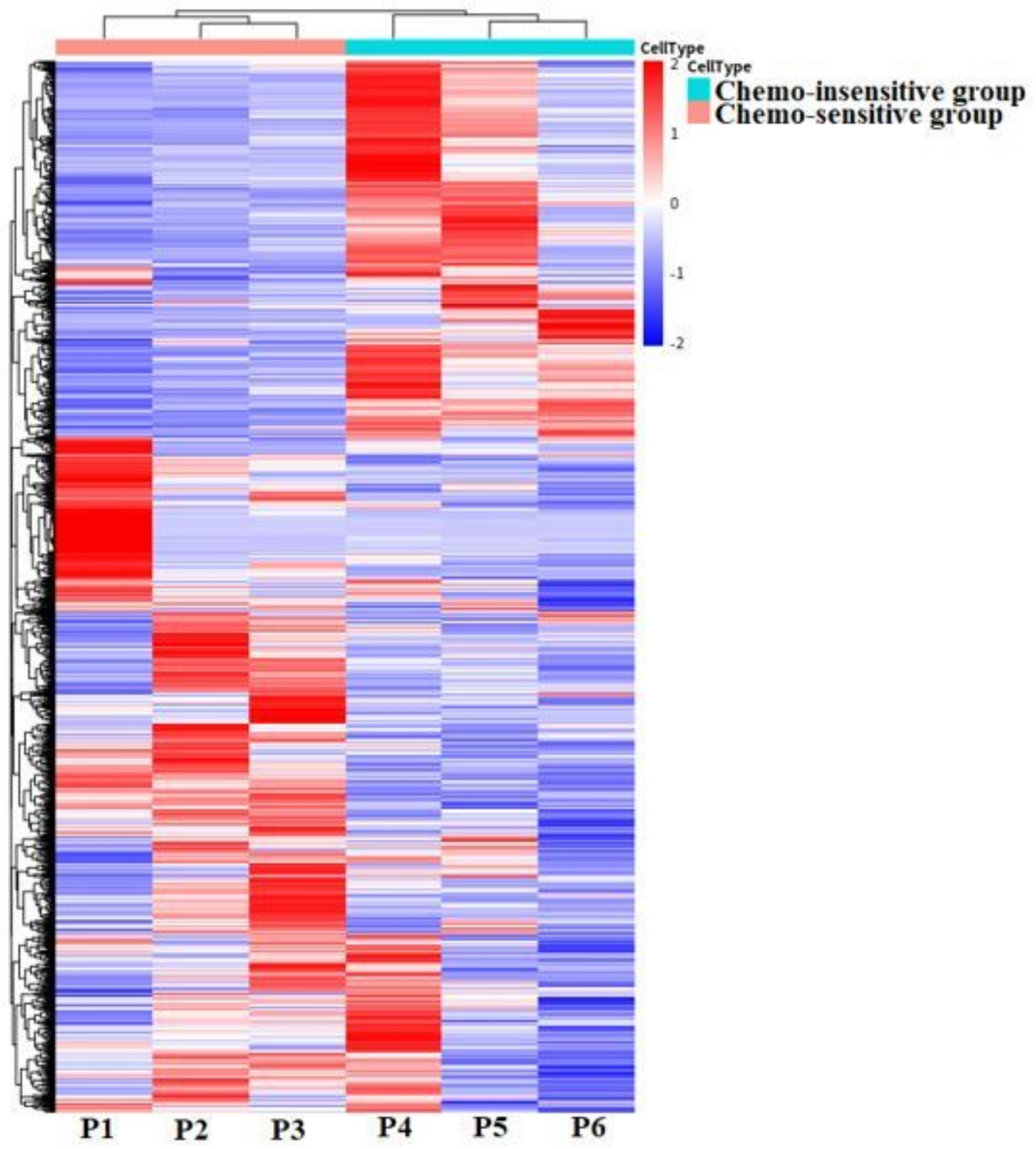

\section{Figure 2}

The heatmap of DMGs in small cell lung cancer. Compared with the group of chemotherapy sensitivity, 1516 coding genes, 205 IncRNAs, and 71 miRNAs were differentially hypomethylated in the chemoinsensitive group. Abbreviation: DMGs, differentially methylated genes; IncRNAs, long non-coding RNAs; miRNAs, microRNAs. 


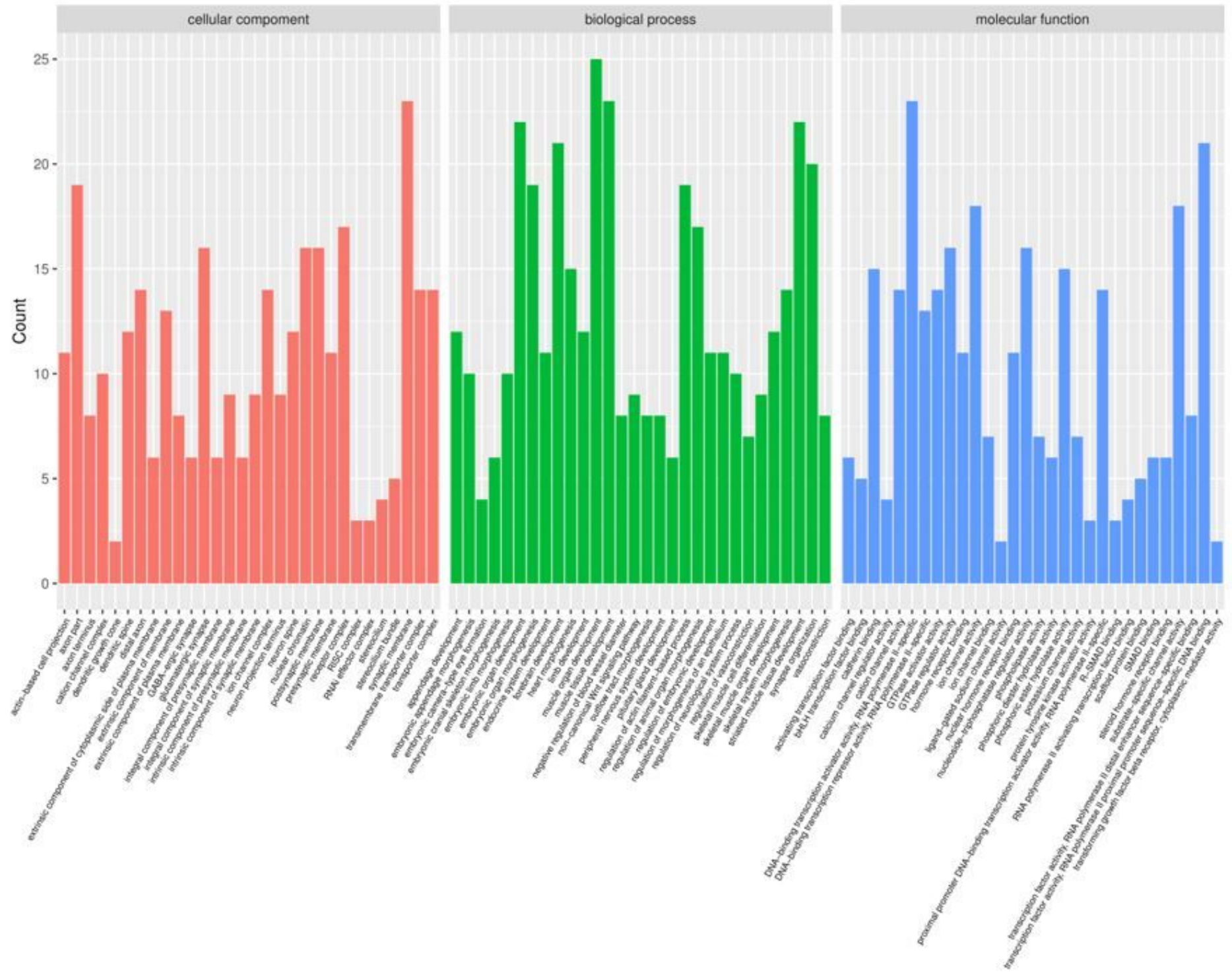

Figure 3

GO enrichment analysis of all DMGs between the chemo-insensitive and chemo-sensitive group. Abbreviation: DMGs, differentially methylated genes; GO, Gene Ontology; IncRNAs, long non-coding RNAs; miRNAs, microRNAs. 


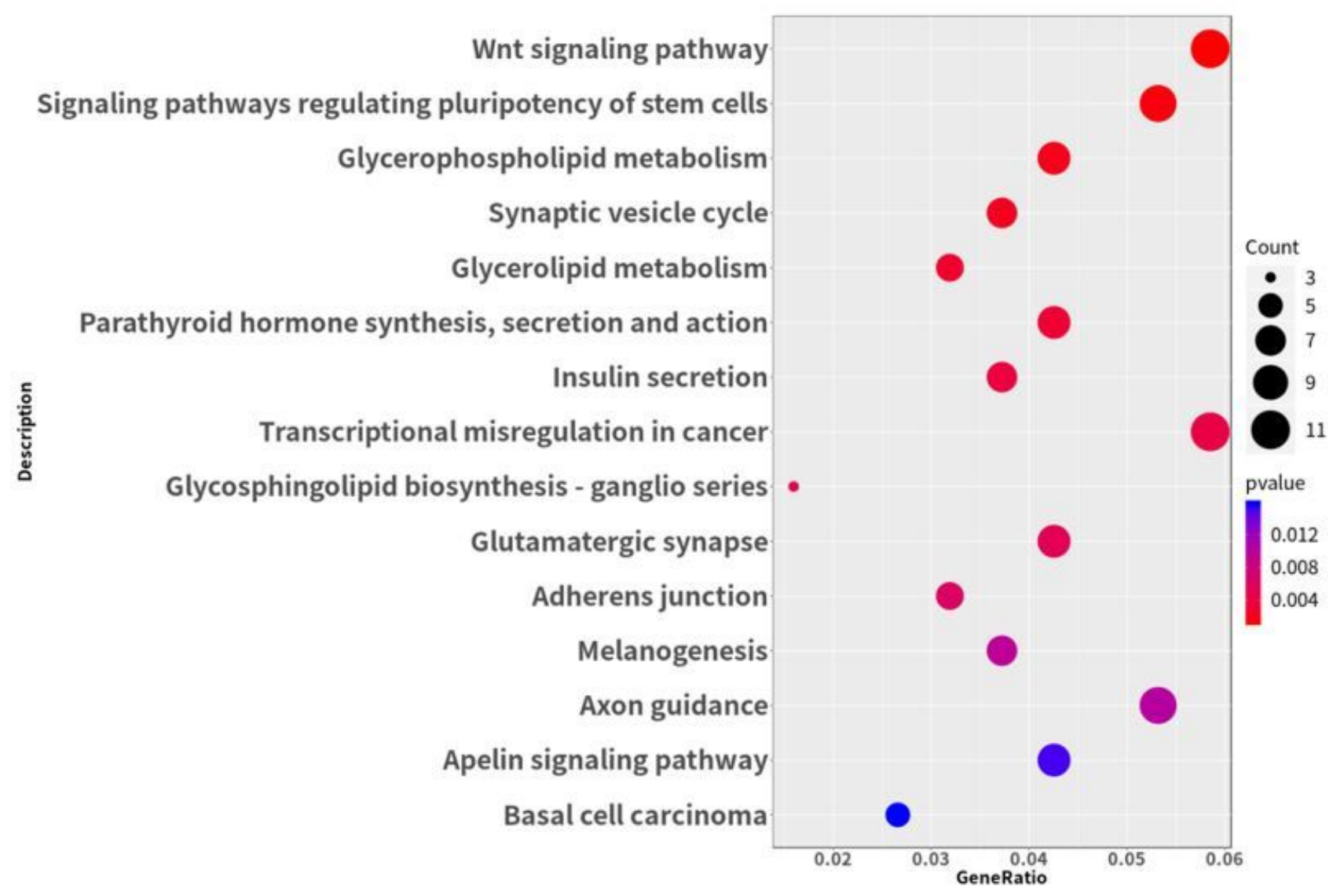

\section{Figure 4}

KEGG pathway enrichment analysis of differentially methylated genes between the chemo-insensitive and chemo-sensitive group. Dot size reflects the number of genes enriched in each signaling pathway. Dot color indicates P-value. Abbreviation: KEGG, Kyoto Encyclopedia of Genes and Genomes.
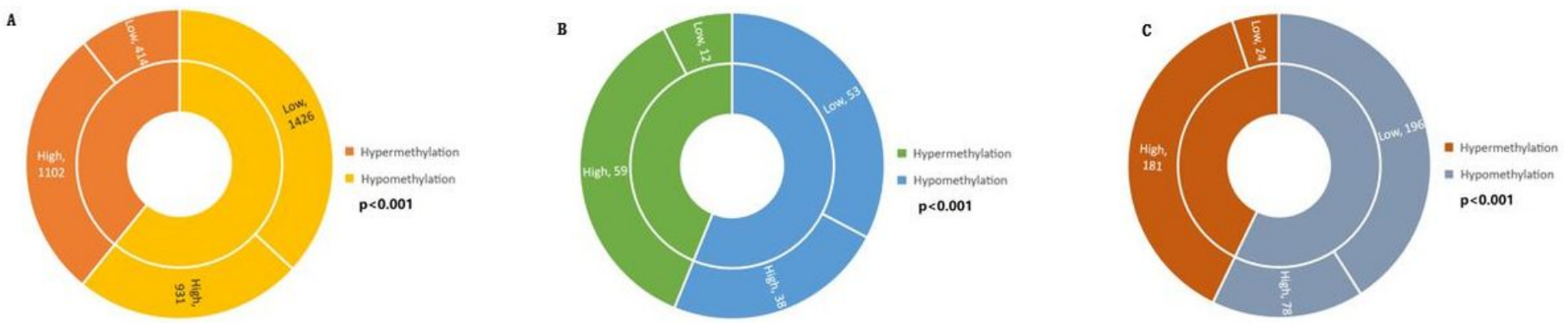

Figure 5

Different expression patterns of genes in SCLC are associated with the levels of methylation. A) The relationship between expression and methylation levels in protein-coding genes. B) The relationship between expression and methylation levels in miRNAs. C) The relationship between expression and methylation levels in IncRNAs. The correlation between methylated status and expression level of DMGs, 
including coding genes, IncRNAs, and miRNAs, was statistically significant (both $p<0.001$ ). Abbreviation: DMGs, differentially methylated genes; IncRNAs, long non-coding RNAs; miRNAs, microRNAs; Low, low expression level; High, high expression level; SCLC, small cell lung cancer; P, P value for whole.

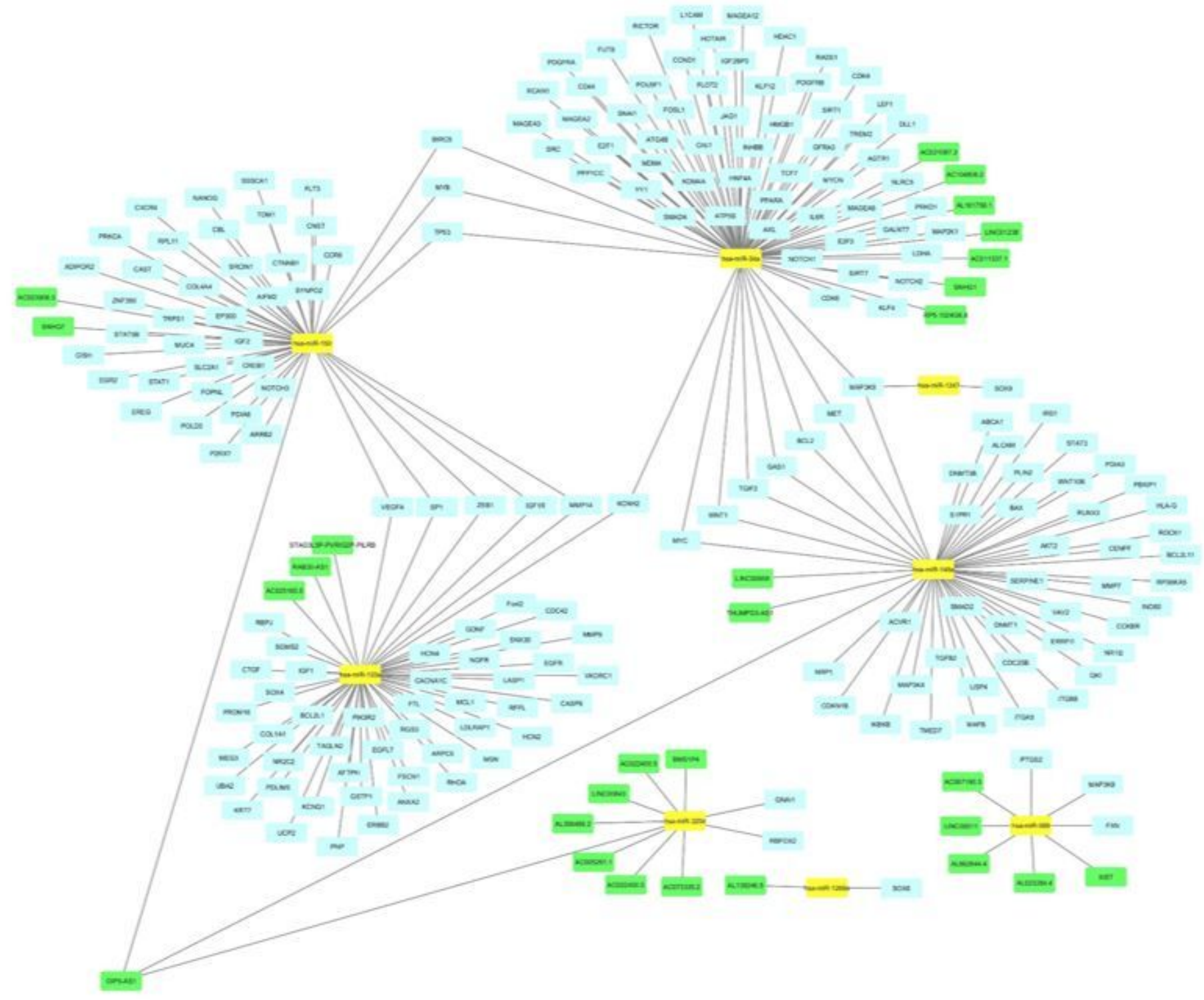

\section{Figure 6}

LncRNA-miRNA-mRNA interaction network for eight miRNAs that hyper- or hypo- methylated in SCLC and showed up- or down- regulated expression. Abbreviation: IncRNAs, long non-coding RNAs; miRNAs, microRNAs; SCLC, small cell lung cancer. 

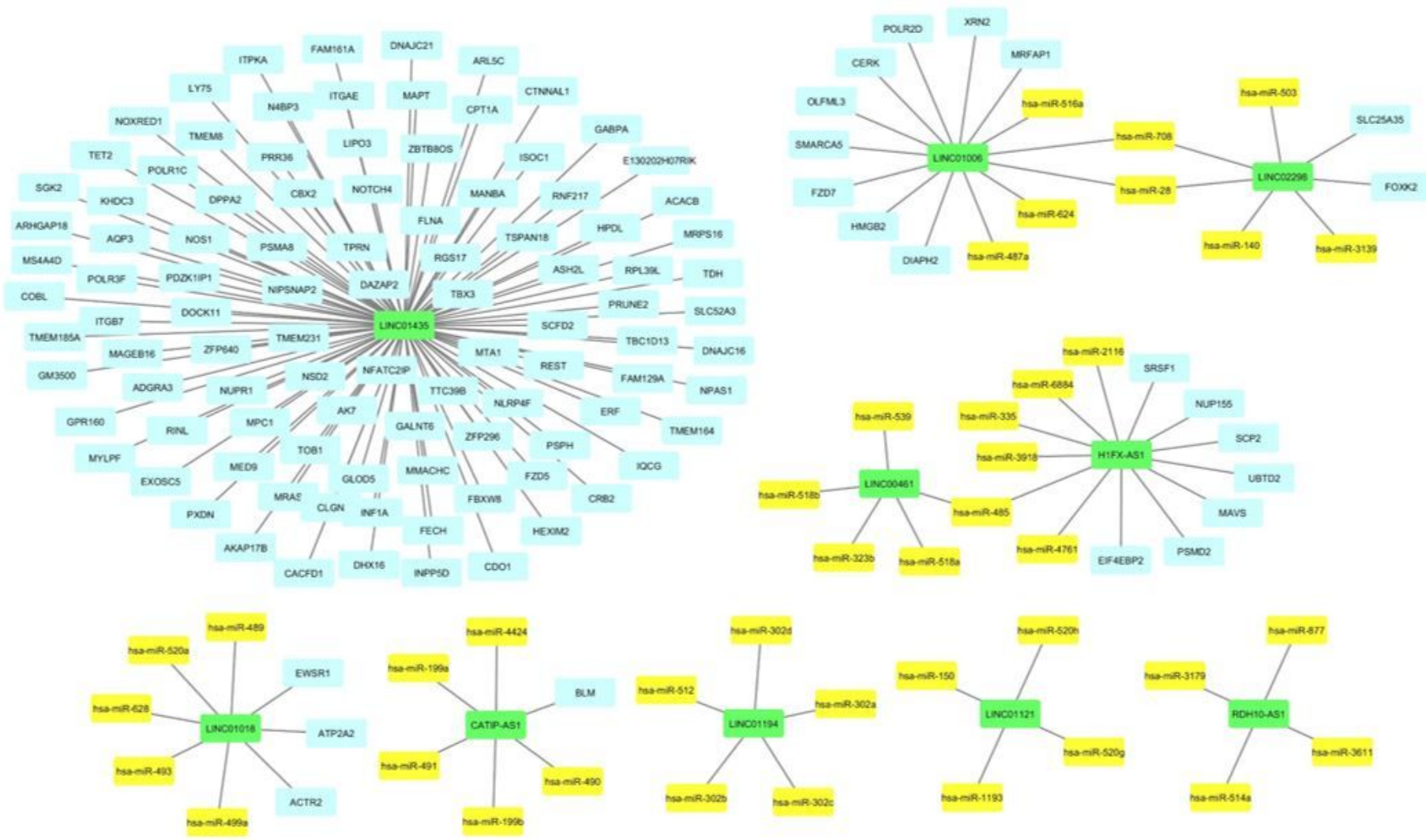

\section{Figure 7}

LncRNA-miRNA-mRNA interaction network for 10 IncRNAs that hyper- or hypo- methylated in SCLC and showed up- or down- regulated expression. Abbreviation: IncRNAs, long non-coding RNAs; miRNAs, microRNAs; SCLC, small cell lung cancer. 


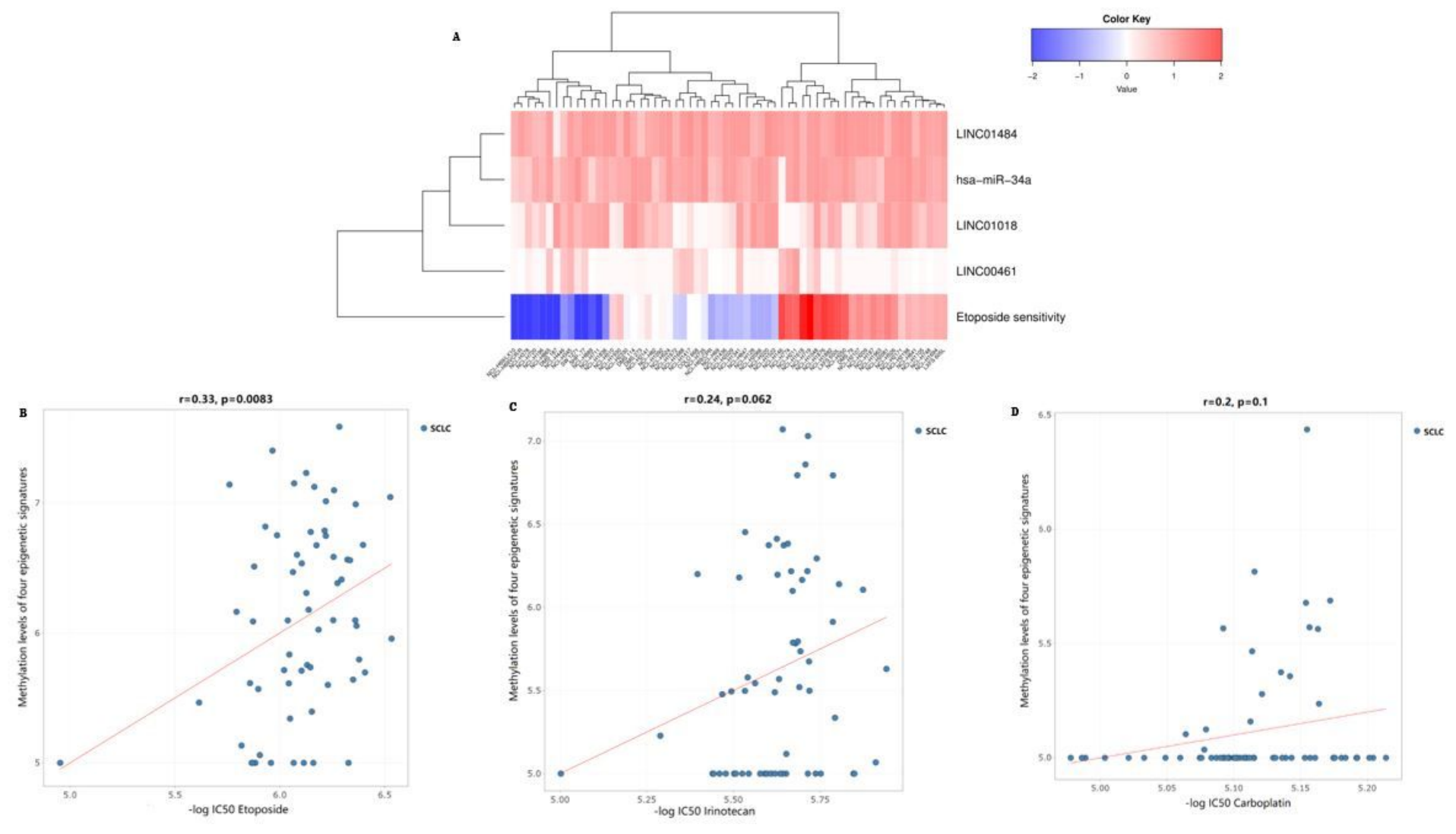

Figure 8

Four therapeutic predictive epigenetic signatures for SCLC based on cancer cell lines drug responses and methylation levels. A) The heatmap displayed the methylation levels of four epigenetic signatures, including hsa-miR-34a, LINC01484, LINC00461, and LINC01018, between SCLC etoposide sensitive and insensitive group ( $N=62$ ). B-D) Scatterplots showed the predictive value of four epigenetic signatures for single drug sensitivity, including etoposide, irinotecan, and carboplatin. Positive correlation between the methylation levels of four genes and all three drugs responses were found. The significant predictive value of four epigenetic signatures were found in etoposide therapy $(p=0.0083)$. Abbreviation: SCLC, small cell lung cancer; r, Pearson's correlation coefficients; $p$, $p$ value for whole.

\section{Supplementary Files}

This is a list of supplementary files associated with this preprint. Click to download.

- SupplementalFigure.docx

- SupplementalFigure.docx

- SupplementalTable.docx

- SupplementalTable.docx 